\title{
النجاح المهني وعلاقته بجودة الحياة لاى المرشدين التربويين
}

\section{م. د مالك فضيل عبدالله القريشي \\ جامعة واسط ـ كلية التربية}

\section{ملخص البحث}

يرهذف البحث الحالي التعرف على درجة النجاح المهني وجودة الحياة ، وكذلك الكثف عن علاقة النجاح المهني بجودة الحياة لاى المرشدين التربوبين ، وقد تحدد البحث الحالي بالمرشدين التربوبين الذين بزاولون مهنة الإرشاد في المدارس الابتدائية المنتسطة والثانوية والإعدادية في محافظة واسط للعام الدراسي

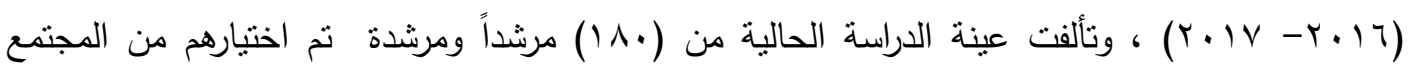
الأصلي للمرشدين التربوبين في المديرية العامة لتربية محافظة واسط والبالغ عددهما (ب (ب) مرشداً ومرشدة ، وقد استعمل الباحث مجموعة من الوسائل الإحصائية المناسبة للوصول إلى النتائج المطلوبة في إجراءات البحث ، وتوصل البحث الحالي إلى النتائج الآتية :

1- أن المرشدين التربويين في محافظة واسط يتمتعون بدرجة جيدة من النجاح المهني. r- أن المرشدين التربويين في محافظة واسط بيتمتعن بدرجة جيدة من الثعور بجودة الحياة

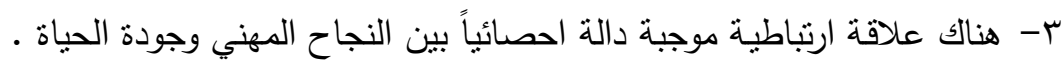

وقد وضع الباحث جملة من التوصيات والمقترحات على أساس النتائج التي خرج بها البحث الحالي . 


\title{
Vocational success and Their Relation with Quality of Life of Educational Counsellors
}

\begin{abstract}
The present study aims at finding out the degree vocational success and quality of Life, it also tries to find out the relation between vocational success in quality of Life for the Educational Counsellors, The present research is limited to educational counsellors who have educating roles at primary, intermediate, seconder, and preparatory school at wassit province during the a cademi year (2016-2017). the sample consists of (180) male and female educational, who are chosen fro a population of wassit directorate which incldes (362) male and female educators the researcher uses certain statirtical tools for analyzing the result obtained .It concluded that:
\end{abstract}

1- Educational counsellors at wassit have a good degree of vocational success.

2- Educational counsellors at wassit have good degree of quality of Life .

3- There is a statistically significant positive correlation between vocational success and quality of life. Basing on the results obtained the researcher puts some suggestions and recommendations. 


\section{الفمل الأول}

مثكالة البمث: -

"يعد الإرشاد النفسي والتوجيه التربوي من المهن الإنسانية والتربوية في آن واحد، إذ يمارس المرشد النفسي دوراً مهماً في تحقيق الأهداف التربوية العامة، وذلك لبناء شخصية الطلبة وتكامل نموهم الاجتماعي

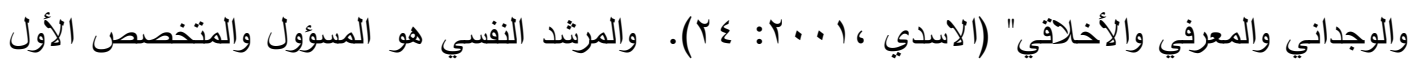
عن العمليات الرئيسية في الإرشاد النفسي لذلك ينبخي أن يتصف بقدرات ومهارات ارشادية عالية تمكنه من

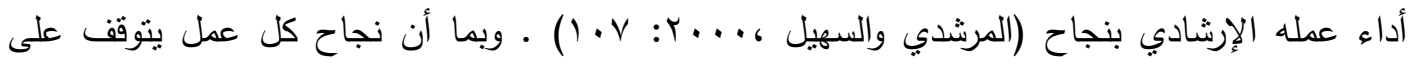
القائمين به ، وعلى ما يتصفون به من صفات ومميزات ، وما يمنلكون من معارف ومعلومات وقدرات واستعدادات ومهارات ، وتحمل مسؤولية ، والرغبة في انجاز العمل ، فان نجاح الإرشاد في المدرسة بوجه خاص يعتمد على المرشدين التربويين لأنهم يشكلونً العنصر القيادي الفاعل في في العملية الإرشادية (Tylor,1996,p.152) "وهذا ما اكدته دراسة كورن هاوز(CornHaws) على نجاح الفرد لدرجة تطبيقه لمهاراته وخبراته وقدراته في العمل مرتبطه ارتباطاً وثيقاً باستقراره النفسي و المهني ، وقد لا يستطيع المرشد النفسي المدرسي من القيام بدوره الارشادي بشكل جيد من دون ان ينوفر له شعور بالقناعة والارنياح

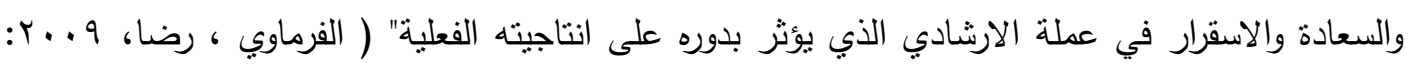

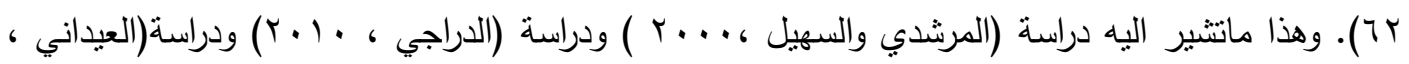

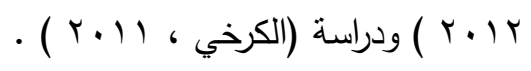

فإن نجاح المرشد التربوي في عمله وحسن أدائه فيه يتوقف بالأساس على نظرته الى ذللك العمل وقبوله ورفضه له ومدى تحقيق ذاته من خلاله ، ووجد الباحث ما تعزز هذه الدراسة هو توجيه سؤال مفتوح على عدد من المرشدين التربوبين للتشخيص مقومات ومعوقات النجاح في العمل الارشادي ، وكذللك زيارة بعض فله المدارس التي يتواجد فيها المرشدين التربويين واجراء مقابلة شخصية معهم وكانت اغلب اجابة المرشدين التربوبين في المدارس التي تمت زيارته ليس لديهم القدرة على تشخيص وحل المشكلات التي تواجه الطلبة وكذلك لديهم معاناه نفسية بسبب عدم تعاون ادارات المدارس معهم وعدم توافر المكان المناسب لبعض المرشدين التربويين يؤثز سلباً على نجاح المرشدين التربوبين في العملية الارشادية ـ وبناءً على ما تقدم يمكن 
تحديد مشكلة البحث الحالي من خلال الاجابة عن التساؤل التالي: ما طبيعة العلاقة بين النجاح المهني

وجودة الحياة لدى المرشدين التربوبين؟

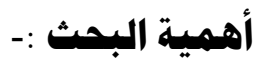

"ومن المعلوم أن الإرشاد النفسي هو أحد العلوم الإنسانية التي تهدف الى خدمة الفرد وسعادته ونتيجة للتطور الحاصل في ميادين الحياة كافة فقد أصبح الإششاد يهتم بالصحة النفسية بوجه عام وزاد اهتمام الإرشاد بفهم الفرد بوصفه انساناً يعيش في مجتمع متغير ومتطور، وبالتالي فهنالك حاجة لتحقيق التوافق والتكيف مع هذا التغير سواء في مجال الأسرة أو العمل أو الدراسة ، ويكون الانسان في تفاعل مستمر مع البيئة ، هذا وأن الارشاد بهتم بتواصل التكيف وتحقيق الصحة النفسية التي تكفل للفرد السعادة "( المرشدي و

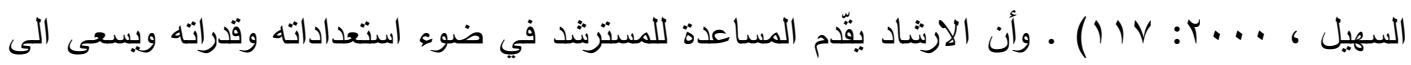
تحقيق قدرة المسترشد على تحقيق ذاته وحياته بنفسه ، وتحديد أهدافهُ في الحياة وتحقيق مطالبه في ضوء معايير المجتمع ( محمود ، 991 1: جب ) • "فالعمل يعد مهماً وأساسياً في حياة المرشدين التربوبين • وهو من أهم المجالات التي تمكنهم من التعبير عن قدراتهم وطموحاتهم وهو من اهم الوسائل التي يمكن عن طريقها إثباع رغباتهم في مختلف الأنشطة الاقتصادية والاجتماعية ، وأن المرشد الناجح في مجال المهنة عليه ان بتمتع بصفات وخصائص عديدة :

أولاً: فيما يتعلق بمفهوم الذات يجب على المرشد الجيد أن يتحلى بالذكاء ، والقدرة على الابتكار ، والإبداع ، والمنافسة المهنية الحرة الثريفة ، والكفاية في إدارة الجلسة النفسية الفردية والجماعية ، والكفاية في القيام

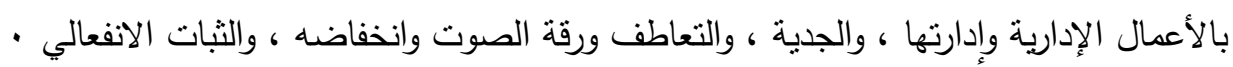

ثانياً: فيما يتعلق بالدافع الثخصي يجب على المرشد النفسي الجيد أن يتصف بالرغبة في النجاح والتقدم في عله والاستقلال الذاتي والمحبة والعمل من أجل الحفاظ على صحته النفسية والجسمية والعمل من أجل بل توفير دخل مادي مناسب وملائم لمظهره ومركزه الاجتماعي لا من أجل الثراء ون ون وله 
ثالثاً : فيما يتعلق بالقيم المسببة للسعادة يجب على المرشد الجيد أن يتمتع بالحرية الثخصية والصدق الواضح المحدد في أقواله والإخلاص المتفاني في عمله والطاقة الثابة على العمل والإنتاج وأخلاق المجتمع الذي يعيش فيه وتعاليم دينه .

رابعاً: الشعور بالآخرين يجب على المرشد الجيد أن يتميز بفهم المسترشد وتحليه بالصبر ، والرقة في تعامله ، والسرور والابتهاج عند المقابلة ، وتشجيع المسترشد وحفظ أسراره ، وعدم التعصب لفكره أو رأى أو مبدأ

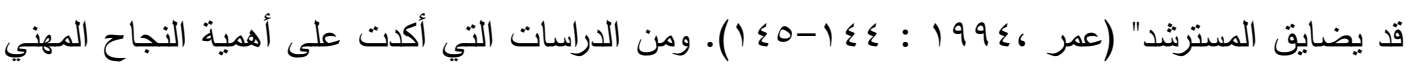
منها دراسة شيرتزر وستون ( •9191) على أن نجاح العملية الإرشادية يعتمد على شخصية المرشد . ولقد اظهرت لنا نتائج البحوث مجموعة من الخصائص المهمة للمرشدين التربويين من بينها أن يكون ذكياً مفكراً مالكاً لقدرات لفظية كافية لعمله راغباً فيه راضياً عنه يمتلك ثقة بنفسه ومتقبلاً لذاته مهتماً بالطلاب مقدراً

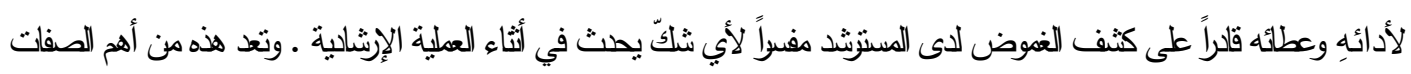

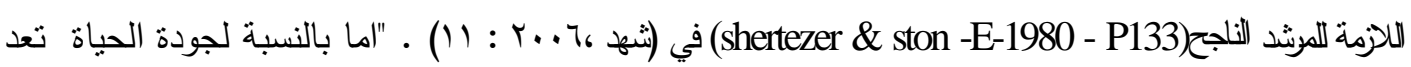
من المفاهيم الحديثة التي لاقت اهتماماً كبيراً في العلوم الطبيعية والإنسانية على سبيل المثال: علم البيئة ،

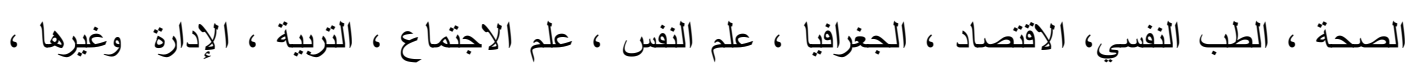
ويرى الباحثون أنه نادراً ما يحظى مفهوم ما بالتبني الواسع على مستوى الاستعمال العلمي أو العملي الهام

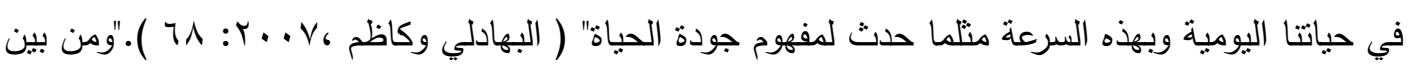
العلوم التي اهتمت بجودة الحياة كان علم النفس من أول العلوم التي تبنت هذا المفهوم في مختلف التخصصات النفسية النظرية منها والتطبيقية ، فقد كان لعلم النفس السبق في فهم وتحديد المتغيرات المؤثزة على جودة حياة الإنسان ، ويرجع ذلك في المقام الأول إلى أن جودة الحياة في النهاية هي تعبير عن

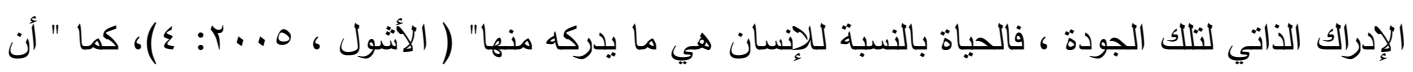
جودة حياة الإنسان تكمن في تفاصيل سلوكه كافة وتصرفاته التي يتبعها ، ولجودة الحياة مقومات تختلف من شخص لآخر حسب ما يراه من معايير تقييم حياته، وتوجد عوامل كثيرة تتحكم في تحديد مقومات جودة الحياة مثل: القدرة على التفكير وأخذ القرارات ، القدرة على التحكم ، الصحة البدنية والعقلية ، العلاقات الاجتماعية ، المعتقدات الدينية والقيم الثقافية ، الأوضاع المالية والاقتصادية التي عليها يحدد كل شخص ما هو الثيء الأهم بالنسبة إليه الذي يحقق سعادتهُ في الحياة التي يحبها، فالصحة هي حالة سلامة بدنية وعقلية واجتماعية وعاطفية ونفسية واقتصادية وتعليمية كاملة وليست مجرد انعدام المرض أو الإعاقة ، ومع بع بل 


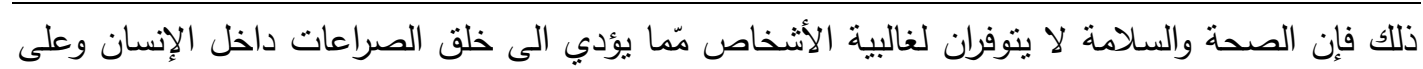

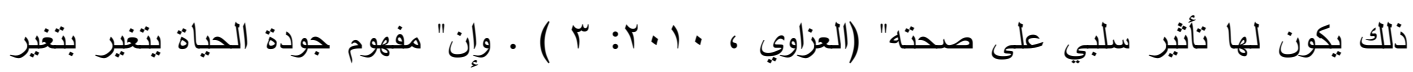

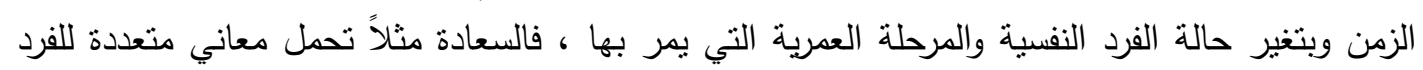
نفسه في المواقف المختلفة فهي بهذا تكون نسبية ، فالمريض يرى السعادة في الصحة والفقير يرى السعادة

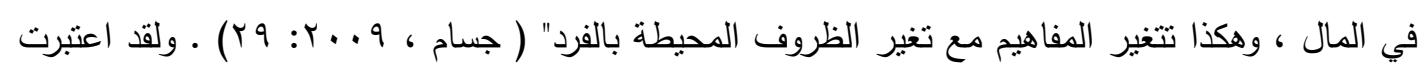

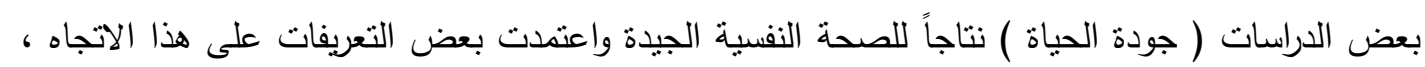

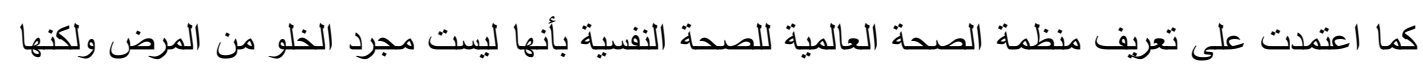
حالة أكثر إيجابية تبدو في الصلاحية الجسمية والانفعالية والاجتماعية أساساً لتفسير جودة الحياة ( Martin

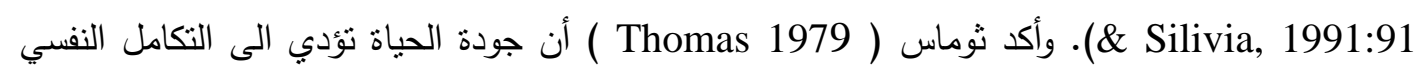
والاجتماعي التي بدورها تجعل الأفراد يتمتعون بصحة نفسية وقدرة على إقامة علاقات اجتماعية تتسم بالرضا

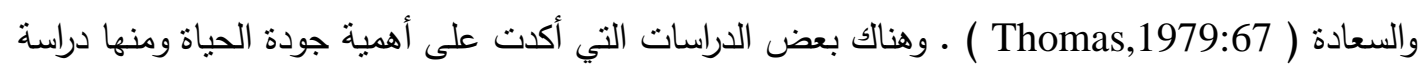

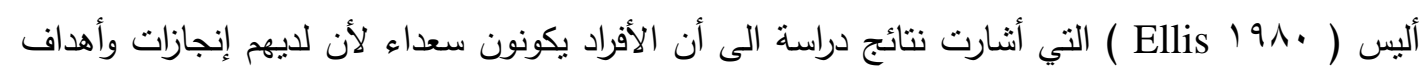

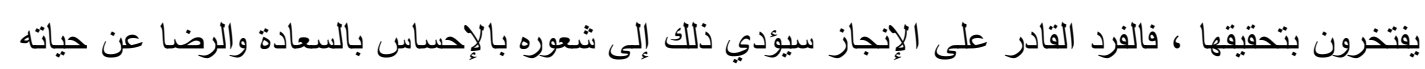

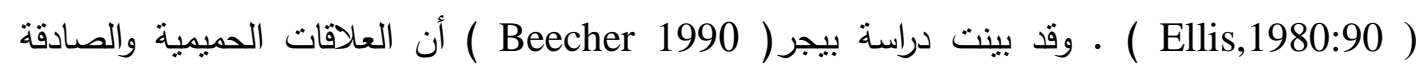
والناجحة تعمل على تقدير الرضا النفسي عن الحياة والثعور بالسعادة ( Beecher,1990:22 ) .

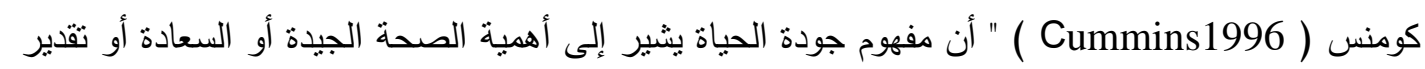

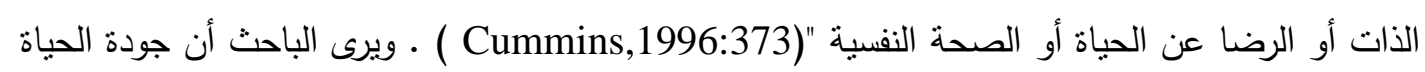

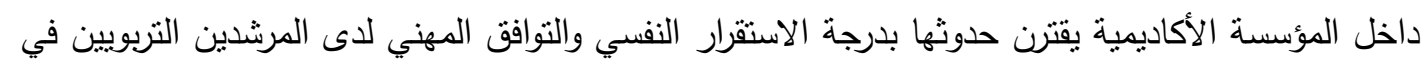

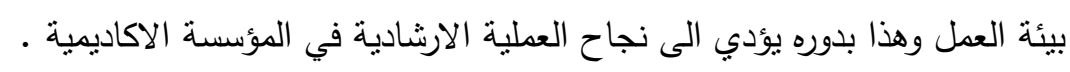

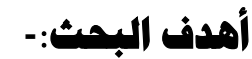

$$
\text { يهذف البحث الحالي التعرف على: }
$$

1- إنة درجة النجاح المهني لاى المرشدين التربوبين. ץ- درجة جودة الحياة لدى للمرشدين التربوبين.

ع- العلاقة بين النجاح المهني وجودة الحياة لدى المرشدين التربويين . «. 1 
يتحدّد البحث الحالي بالمرشدين التربويين في المديرية العامة لتربية محافظة واسط للعام الدراسي ( 1 ( ـ.

\section{تحديد المطاحات:- \\ جودة الحياة فعرفها كلا من:-

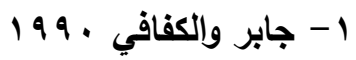

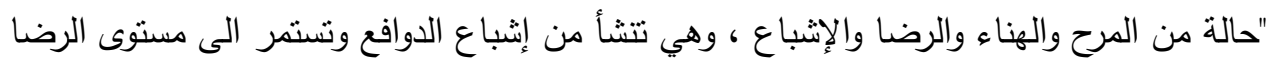

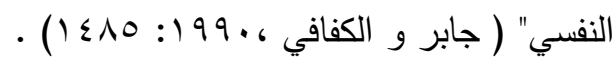

: r..

"ثعور الفرد بالسعادة والمعنى في حياته والذي يتحقق عن طريق تحقيق الأهداف واستثمار طاقاته بالتعامل

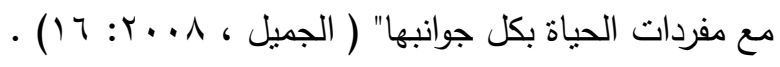

$$
\text { ب }
$$

"قدرة الفرد على التوازن في علاقاته الأسرية والاجتماعية والمهنية ، عن طريق حب الناس والتسامح

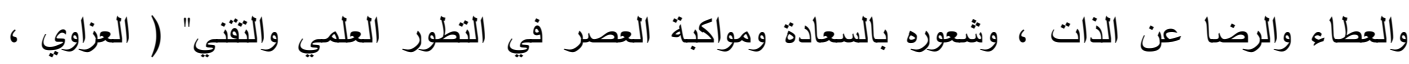
. ( $17: r \cdot)$.

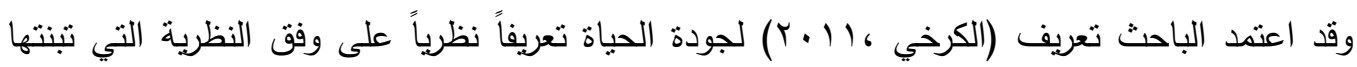

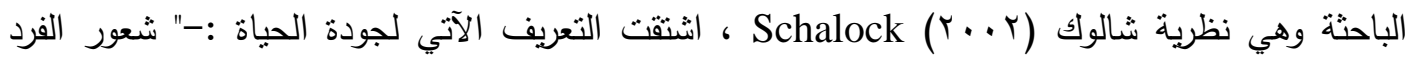

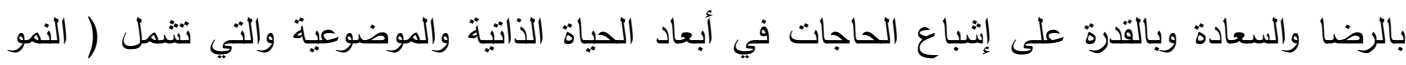

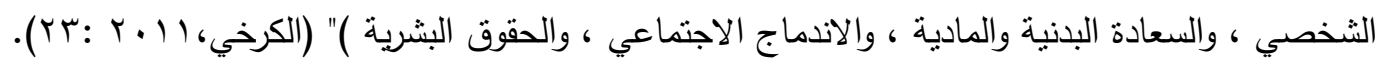


اما التعريف الأجرائي للجودة الحياة :" فهي الدرجة الكلية التي يحصل عليها المرشد التربوي خلال الاجابة

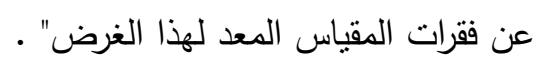

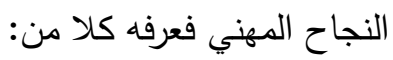

$$
\text { - }
$$

"توفر ما يفي المهمة حقّها في الأداء من امتلاك المعرفة الضرورية والمهارات والاتجاهات اللازمة لبلوغ

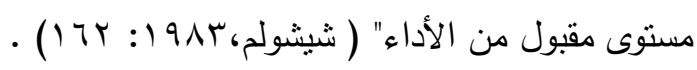

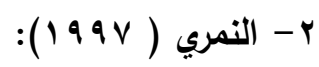
هو الحدّ الذي يصل إليه الموظف من أداء عمله وإثقانه " (النمري، 999 ا: ع ؟).

\section{التعريف النظري}

\section{يعرف الباحث النجاح المهني :}

هي قدرة المرشد على القيام بالمهام التي تطلبها مهنة الإرشاد بمستوى معيّن من الاتقان يضمن تحقيق

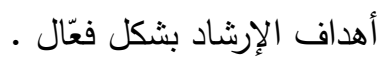

أما التعريف الإجرائي للنجاح المهني : "فهي الدرجة الكلية التي يحصل عليها المرشد التربوي من خلال الاجابة عن فقرات المقياس المعد لهذا الغرض" . لاجئ

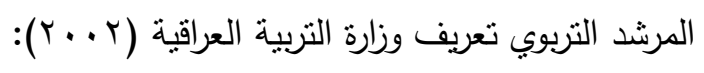

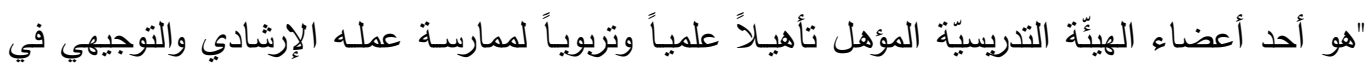

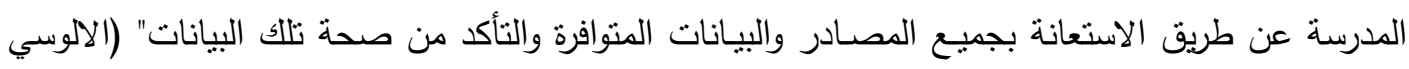

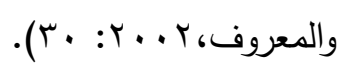




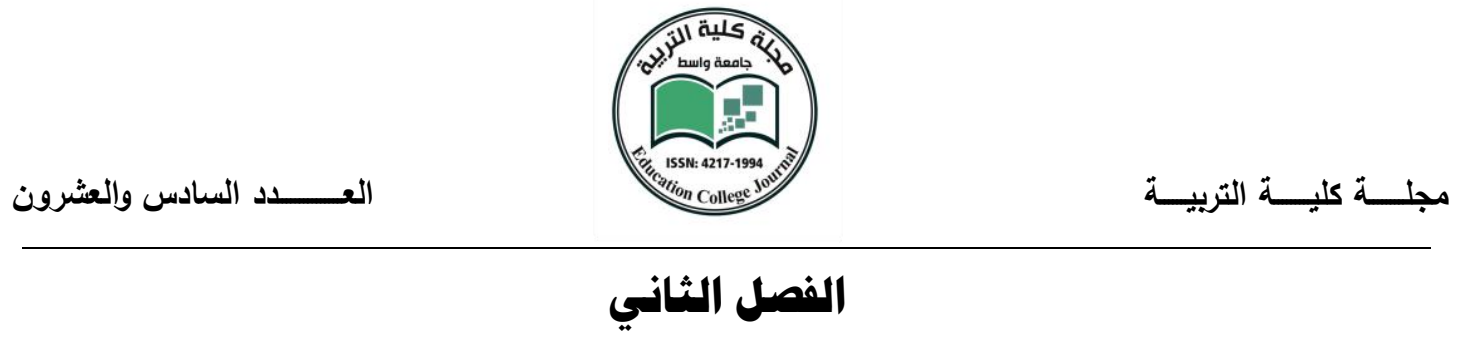

اولاً :الاطار النظري:

مفهوم النجاح المهني:

" يُعدّ مفهوم النجاح المهني من الكثر المفاهيم النظرية والعلمية التي نالت اهتمام المسؤولين في مختلف المهن في السياسة والإعلام، وفي الصناعة والاقتصاد وفي الصحة وفي مجال التربية والتعليم وفي غيرها من المجالات الأخرى ، إذ عدّها البعض بأنها المقدرة أو الأهلية للقيام في العمل ،ومنهم من عدها القيام

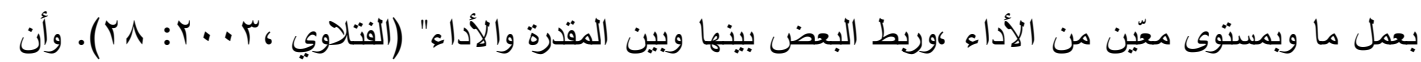
النجاح المهني يُعدّ مجموعة القدرات التي يسفر عنها من المعارف والمهارات والاتجاهات التي يمتلكها

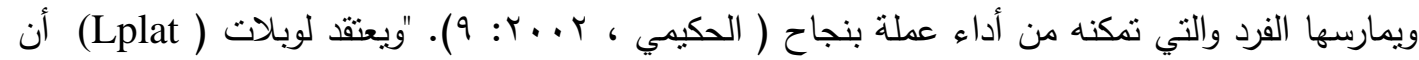
مفهوم النجاح لا يختلف كثيراً عن بعض المفاهيم القريبة مثل الكفاية ، المهارة ، وحسن الأداء ، والخبرة ، والقدرة ، ويتضمن النجاح المهني ثلاث عمليات أساسية هي :الانتقاء المهني ،والتوجيه المهني ، والتدريب المهني ، وذلك لاختيار أفضل المتقدين لشغل وظيفة ما ويكون الاختيار بمثابة مواعمة بين متطلبات الوظيفة من القدرات والإمكانات ومن ثم التعرف على سمات الأفراد وخصائصهم الفنية وقدراتهم الذاتيـة

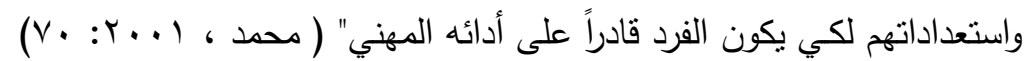

\section{النظريات التي تناوات النجاع المهني :}

اولاً : نظرية الكفاح من اجل التفوق ( ادلر ، 979 ( ) )

"بعتبر ادلر الكفاح من أجل التفوق الحقيقة الأساسية لحياة الإنسان وأن هناك أساليب سلوكية للوصول إلى هذا الهدف إذ يحاول كل شخص تحقيق التفوق بأسلوب سّماه ( أسلوب الحياة ) الذي يتضمن الأنماط السلوكية التي يقوم بها الفرد للتعويض عن مشاعر النقص لديه ويرى ادلر أن الكفاح في سبيل التفوق ضرورة الحياة وأن الانسان تحركه توقعاته للمستقبل اكثر من تحركه خبراته الماضية، مما يرى أن الكفاح في سبيل التفوق قد يعرب عن نفسه بطرق عديدة ومختلفة وأن لكل شخص أسلوباً خاصاً به لبلوغ النجاح أو محاولة 
بلوغه و يرى ادلر ان السلوك اياً كان نوعه يمكن تفسيره بانه محاولة من الفرد للسيطرة على الغير وأن

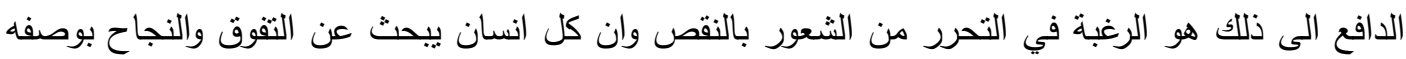
وسيلة تعويض" • ويمكن تفسير النجاح المهني والذي يعني إتمام الفرد للمهام الموكلة اليه بشكل جيد باتخاذ العديد من السلوكيات كأساليب للحياة لغرض تحقيق التفوق والذي تدفعه الرغبة في التحرر من مشاعر النقص المنتوعة(هول ، 1979 : : 1979 (1) ).

ثنانياً : نظرية التوقع ( فروم ، ؛ 94 )

"برى فروم ان النجاح في العمل او عدمه هو نتيجة لموازنة الفرد بين ما يتوقع الحصول عليه من فائدة

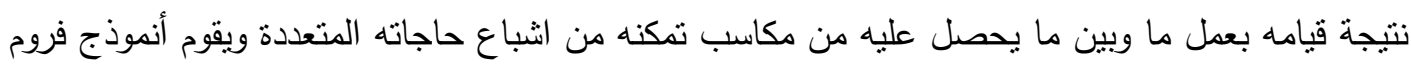

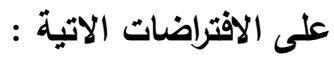

ا-أن نجاح الإنسان تحدده قوى نابعة من داخله ومن بيئة العمل التي يوجد فيها.

r- يختلف الناس في حاجاتهم وأهدافهم، فهم يختلفون فيما يريدون من المؤسّسات التي يعملون بها. ب-أن قوة الدافع عند الفرد تعتمد على مدى توقعه في النجاح للوصول إلى ذلك الإنجاز وهذا التوقع الأول، الكا،

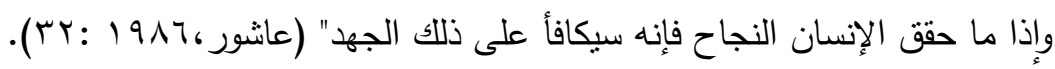

ثالثاً : نظرية الحاجة للانجاز (ماكيلاند Vד 9 ( ) )

اقترح ( ماكيلاند ) عدة افتراضات لعوامل النجاح عرفت ( بنظرية الإنجاز ) التي تركزت على ثلاث

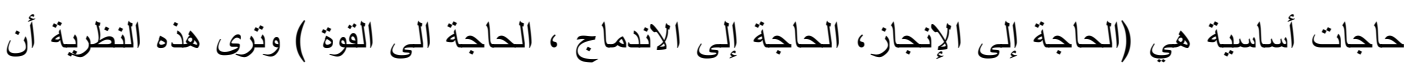

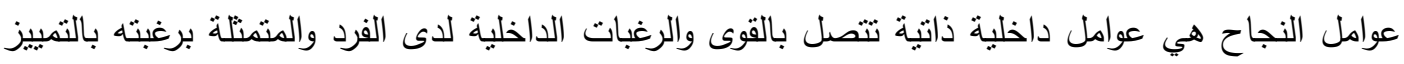

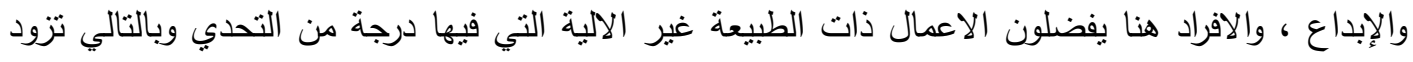

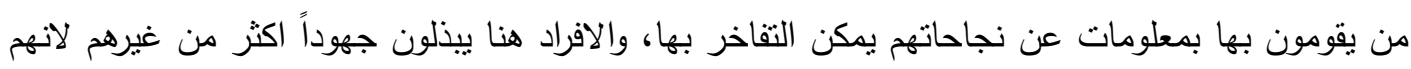

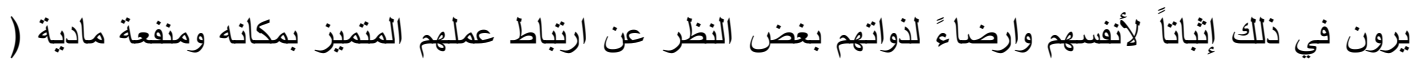

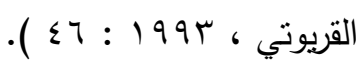




\section{هفهوم جودة المياة}

"تتاولت الفلسفة مفهوم جودة الحياة بوصفه دافعاً أساسياً للسلوك الإنساني فإنّ جميع الفلاسفة الإغريق قدموا أفكاراً تتفق حول معنى هذا المفهوم على أنّه يأني من معرفة الحقيقة ومن تطهير الإنسان نفسه في الانفعالات المكبوتة أو المؤلمة التي تأتي من خلال وجوده مع أثخاص آخرين أو نقيض ذللك وهو العزلة والتفكير الفردي المنعزل" ( Myers-1995-p:12 ). ويُعّد مفهوم جودة الحياة من المفاهيم التي يصعب

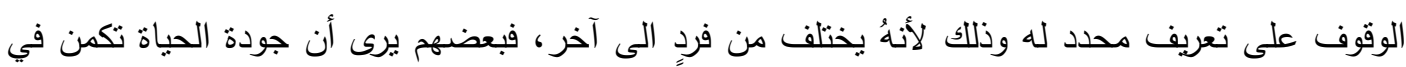
الإنجاز وبعضهم يراها في امتلاك المادة والبعض يرى إنها تكمن في السعادة والصحة ، يضاف الى ذلك

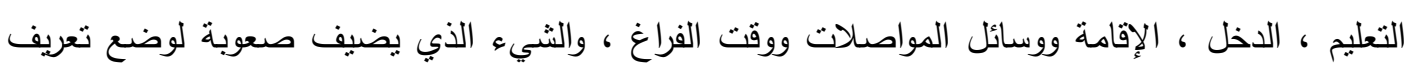
محدد لجودة الحياة أنه لا يوجد اتفاق حول ما إذا كان قياس جودة الحياة ينم من الناحية الموضوعية أم من الناحية الذاتية ، كما يوجد شيء هام يزيد من صعوبة تحديد مفهوم جودة الحياة وهو أن معظم الناس ينظرون إلى جودة الحياة من الناحية الإيجابية فقط مثل جودة الحياة العالية والرضا عن الحياة، بينما يمكن أن تكون جودة الحياة سلبية فجودة الحياة المنخفضة تعني عدم تحقيق ما يتمناه الفرد وتوجد على شكل شعور باليأس

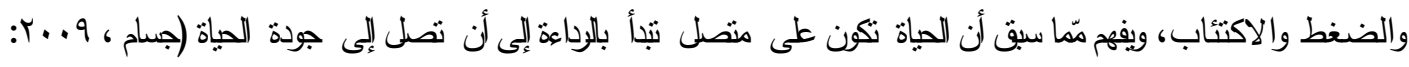

\section{النظريات التي ثناولت جودة المياة :}

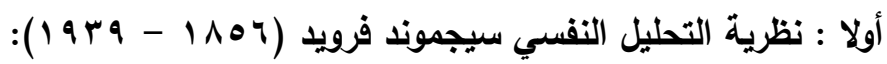

تُعد نظريّة التحليل النفسي التي وضعها فرويد عام ( /NA1 ) من أقدم النظريات وأبرزها التي فسحت المجال للكثير من عُلماء النفس للاراسات النظرية والتجريبية ، أن الإطار الفلسفي الذي انطلق منه فرويد في نظريته كان من أسس بيولوجية وذلك يرجع لطبيعة العمل الذي عمل فيه وهو مجال الطب ، وقد ظهر

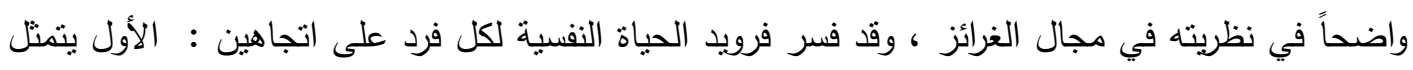
في البناء الجسمي والعضوي للإنسان، وذلك عن طريق الجهاز العصبي، أما الثاني فيتعلق بالأفعال الثعورية لدى الفرد، وأما ما يكون فهو المجهول في منطقة اللاشعور ( الزيود ، 1 . . 1 : 19 ). وقد ذكر فرويد أن جودة الحياة هي شعور الفرد بالسرور والسعادة وتخفيف الالام وهي هدف أساسي للسلوك البشري وكذلك 


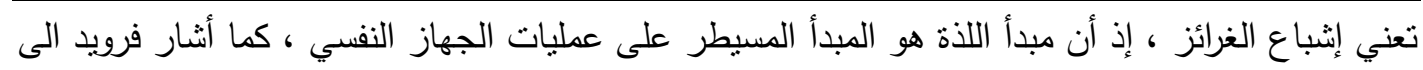

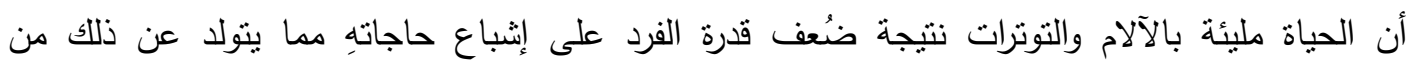

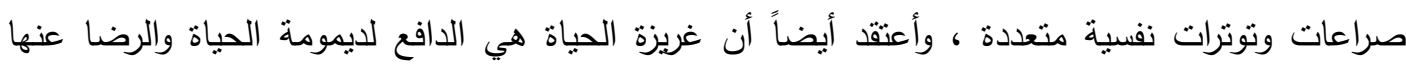

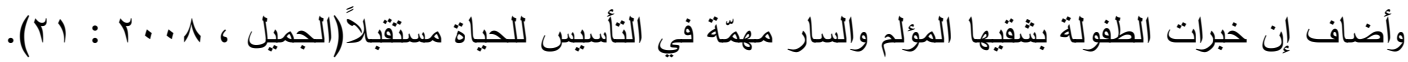

$$
\text { ثانياً : إبراهام ماسلو ( 19.1 - . 19v ) ): }
$$

وأكذَ ماسلو في نظريتهِ ( نظرية الحاجات ) أن هُناك مجموعة حاجات أساسية ومجموعة حاجات ثانوية

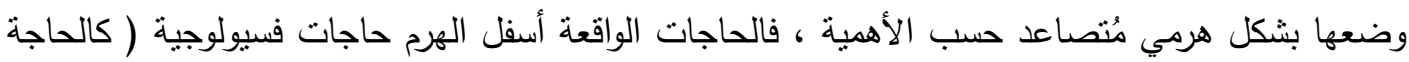

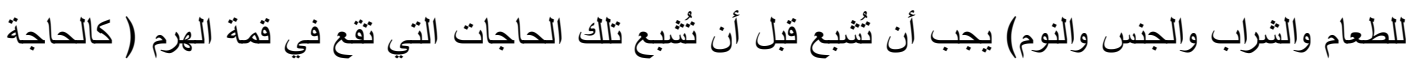

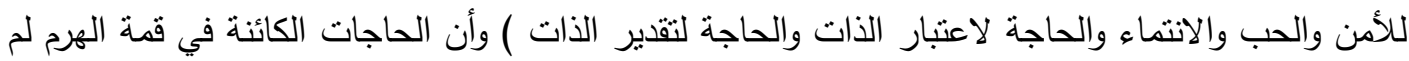

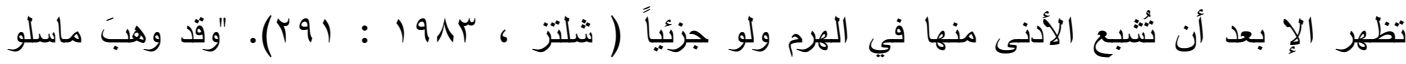

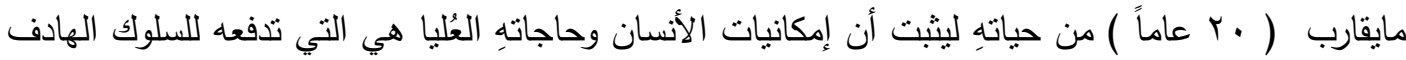

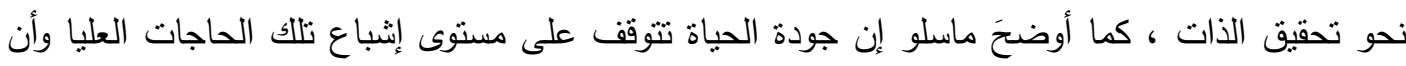

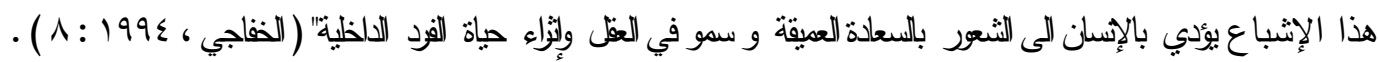

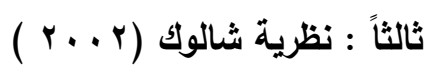

" تدور هذه النظرية من جودة الحياة عن محددات أخرى لمؤشرات جودة الحياة ، إلا وهي جودة الحياة

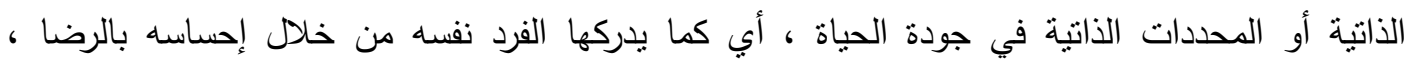

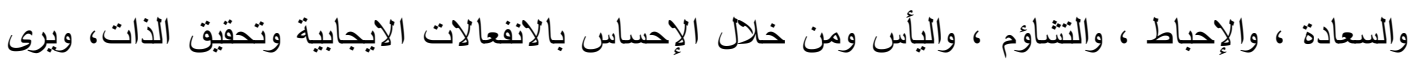

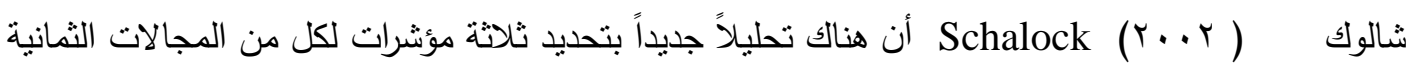
لجودة الحياة وعلى النحو الآتي : لجن

1. السعادة الانفعالية : وتتشل الرضا ، ومفهوم الذات ، وانخفاض الضغوط ·

r. العلاقات بين الثخصية : تثمل التفاعلات والعلاقات والمساندة •

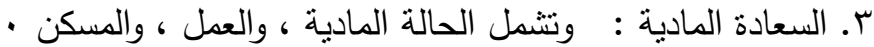


ع. النمو الثخصي : ويشمل التعليم ، والكفاءة الثخصية والأداء. • م.

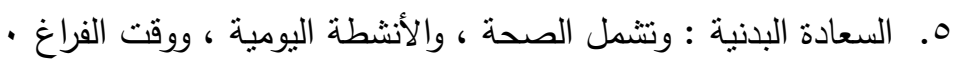

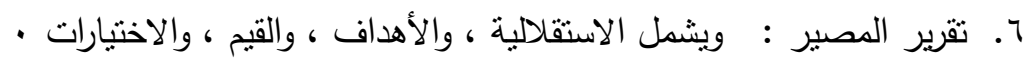

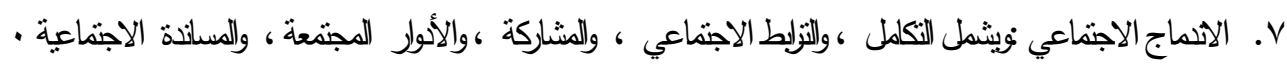
^. الحقوق البشرية والقانونية والعمليات الواجبة :هي رضا الفرد الدتعلق بإدراكه لحقوقه الفردية وحقوق

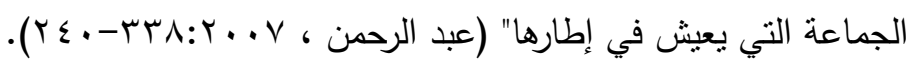

ثانياً : الاراسات السابقة:

يتضمن هذا الجزء من الفصل الثاني بعض الدراسات السابقة التي تتعلق بمتغيرات البحث التي تمكن الباحث من الحصول عليها والاستفادة منها. ونظراً لندرة الدراسات المحلية والعربية والاجنبية التي نتاولت

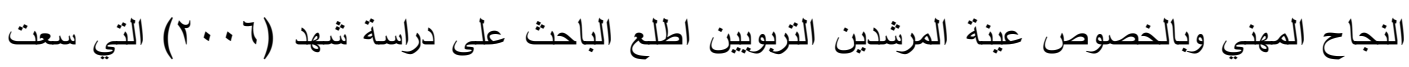
الى التعرف على النجاح المهني والرضا الوظيفي والعلاقة بين المتغيرين لدى المرشدين التربوبين من وجهة نظر مدرائهم ، وتألفت عينة البحث من ( • (T) مديراً ومديرة ، وللوصول إلى نتائج البحث قام الباحث ببناء مقياس النجاح المهني وتبنى مقياس الرضا الوظيفي المعد من قبل النعيمي ( . . . ب)، وأظهرت نتائج البحث أن المرشدين التربوبين من وجهة نظر مدرائهم لديهم نجاح مهني ويتمتعون بدرجة مناسبة من الرضا الوظيفي وكذلك وجود علاقة ارتباطية بين درجات مقياس النجاح المهني والرضا الوظيفي أمّا الدراسات التي تخص

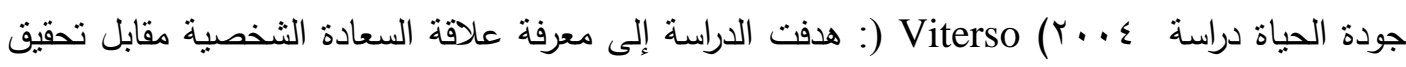

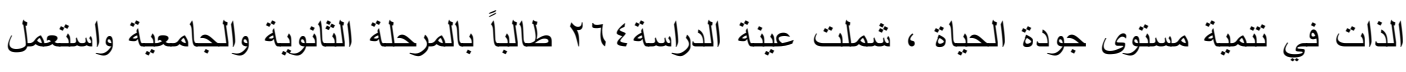
مقياس السعادة الثخصية ومقياس تحقيق الذات ومقياس آخر لجودة الحياة لتحقيق أهداف الدراسة ، وأسفرت نتائج الدراسة عن وجود علاقة ارتباطية موجبة بين كل من السعادة الثخصية وتحقيق الذات من ناحية وجودة الحياة من ناحية أخرى و إن السعادة الشخصية عامل قوي برتبط بجودة الحياة مقارنة بتحقيق الذات أمّا دراسة عبداله(^ + . ץ) هدفت الدراسة إلى معرفة طبيعة البناء العاملي لجودة الحياة في البيئة العربية ، وتعرف أثز متغيرات ( النوع ، الحالة الاجتماعية ، الحالة المهنية ، العمر) والتفاعل بينهما ، وكذلك تعرف إمكانية التتبؤ بمستوى جودة الحياة من درجة الثُعور بالصحة النفسية ، بلغت عينة الدراسة ( سلبر ) طالباً وطالبة من طلبة الصفوف الرابعة بكليات التربية ، الآداب ، العلوم الإنسانية ) وطلاب الدراسات العليا 
ببرنامج الدبلوم التربوي بجامعة الملك عبدالعزيز، واستعمل في الدراسة مقياس مكون من (V • ( ) فقرة ، أعده الباحث في ضوء معايير جودة الحياة التي وضعتها منظمة الصحة العالمية ، أمّا الوسائل الإحصائية

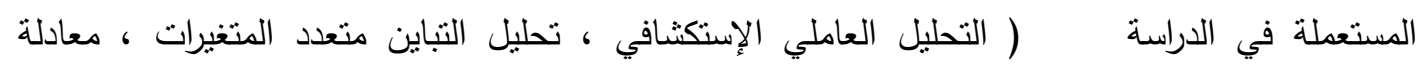

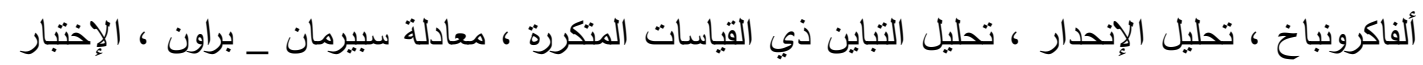

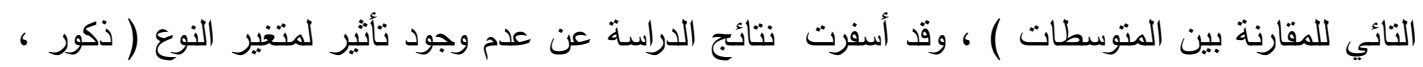

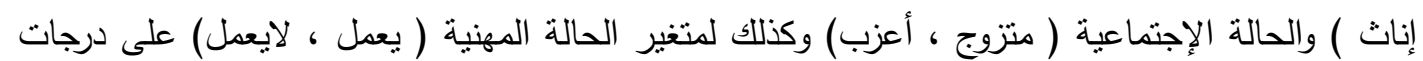

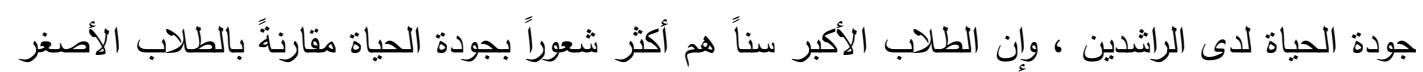

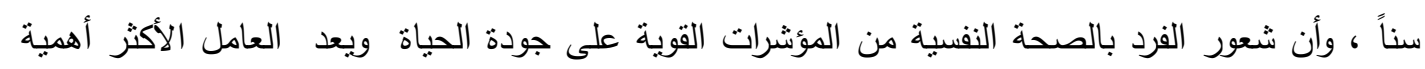

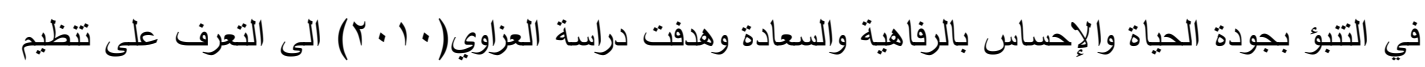

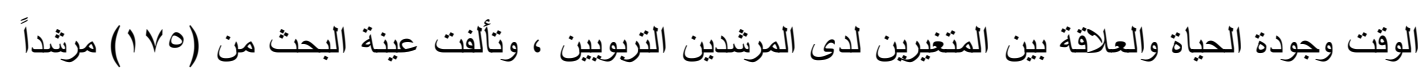

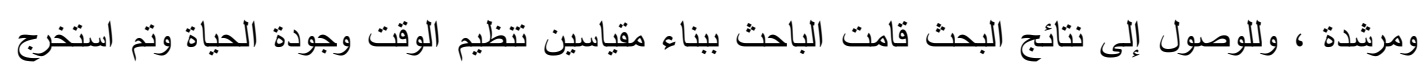

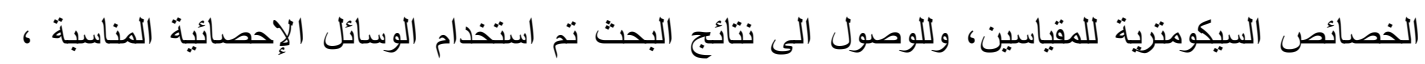

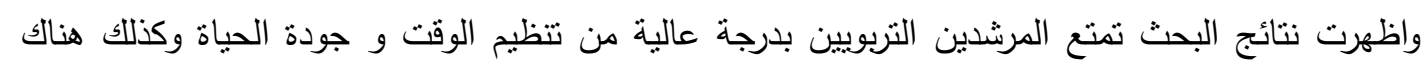

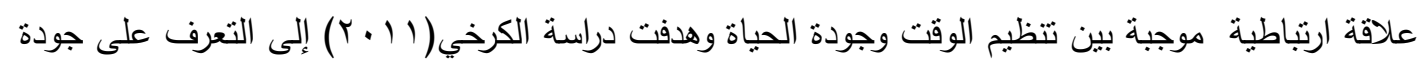

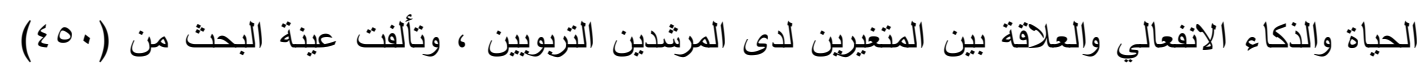

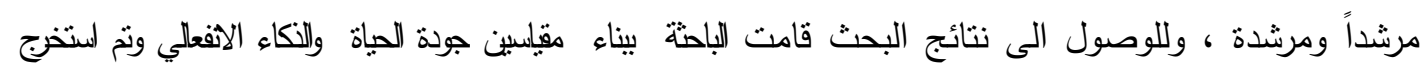

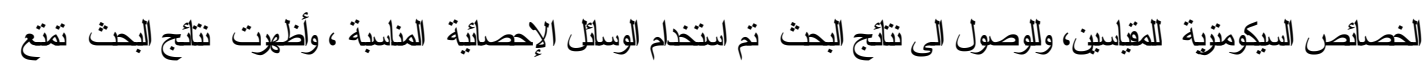

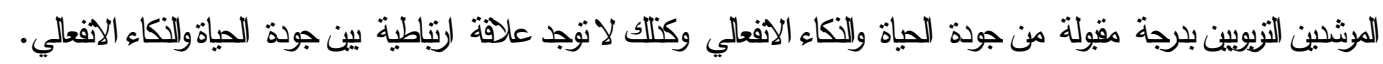




\section{الفصل الثالث}

\section{هنهبية البحث وإجراءاته:}

منهجية البحث:

استخدم الباحث "المنهج الوصفي بوصفه أنسب المناهج لدراسة العلاقات الارتباطية بين المتغيرات من أجل وصف الظاهرة المدروسة وتحليلها، إذ إن المنهج الوصفي يمكن استخدامه في دراسة السمات والقدرات والمهارات والميول والاتجاهات وتعتمد دراسة الظاهرة على ما توجد عليه في الواقع ويهتم بوصفها وصفاً دقيقاً"

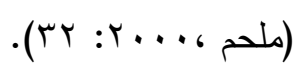

\section{مجتمع البحث:}

يشتمل مجتمع البحث الحالي على جميع المرشدين في المدارس المتوسطة والثانوية والإعدادية المشمولة بالإرشاد التربوي في محافظة واسط والبالغ عددهم (rrr) مرشداً ومرشدة الذين يزاولون مهنة الإرشاد في مدارس المديرية العامة للتربية محافظة واسط حسب الكتاب الصادر من المديرية العامة للتربية محافظة واسط

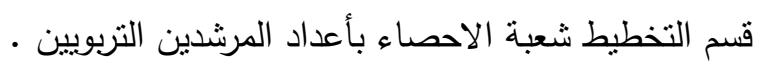

عينة البحث:

بلغت عينة البحث التطبيقية (، (1) مرشداً ومرشدة ، نم اختيارهم بطريقة الطبقية العشوائية من مجتمع

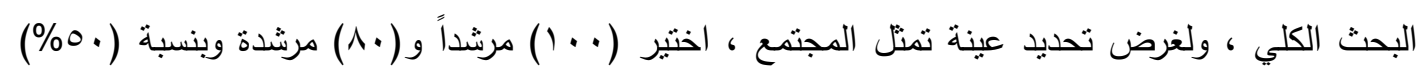
تقريباً من المجتمع الاصلي للبحث. 
لغرض تحقيق اهداف البحث، ينطلب اعداد مقياس للنجاح المهني لاى المرشدين التزبويين ومن خلال اطلاع

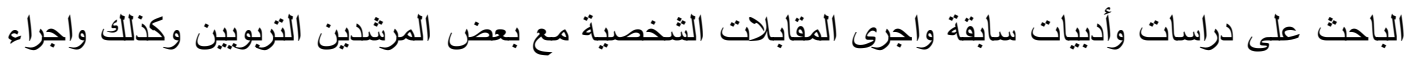

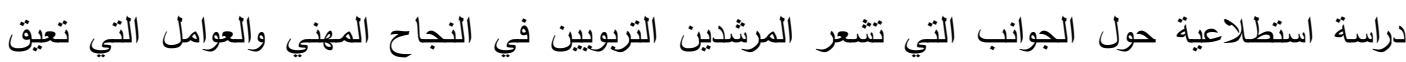

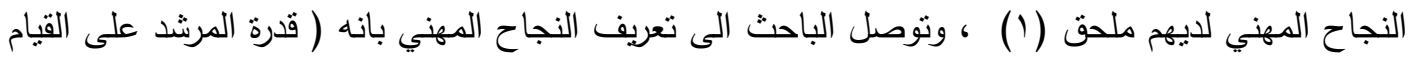

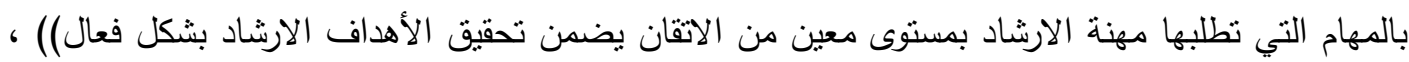

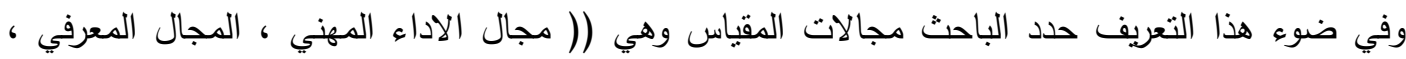
المجال النفسي ، المجال القيمي)). الخصائص القياسية (السيكومترية ) للمقياس :

"لقد أثنار المتخصصون في مجال القياس والتقويم النفسي أن الخصائص السيكومترية للمقياس تتضمن

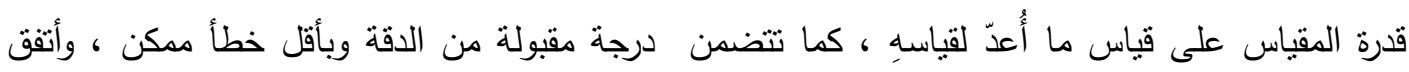

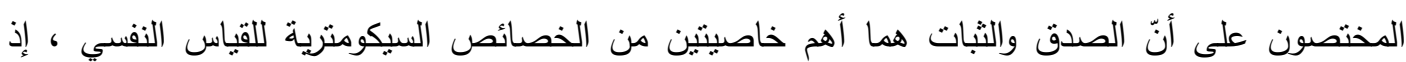

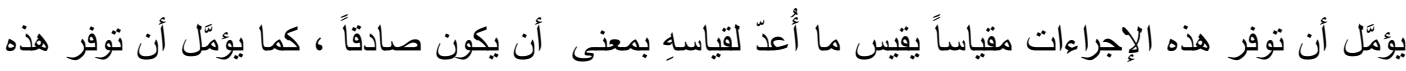

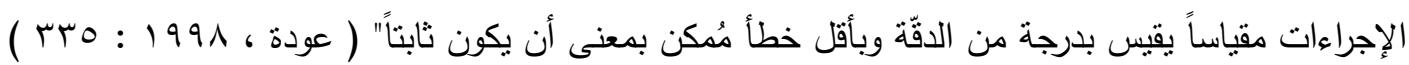
• وقد تحقّق الباحث من الخصائص السيكومترية على النحو الآتي:

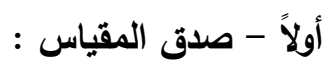

ويقصد بالصدق أن يقيس المقياس فعلاً ما وضع لقياسه ، ويُعد الصدق من الثروط الضرورية

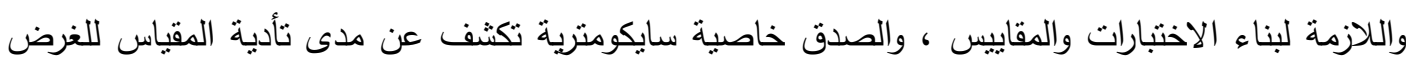

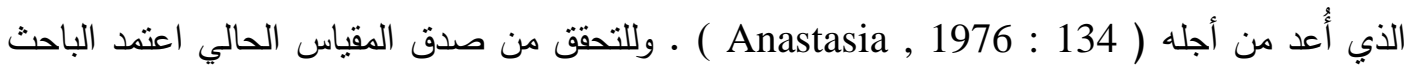

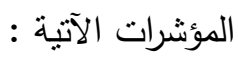


قام الباحث بعرض المقياس على مجموعة من المحكمين في العلوم التربوية والنفسية ملحق(ץ) للأخذ بآرائهم وملاحظاتهم ، وقد حصلت الفقرات جميعها على نسبة اتفاق الخبراء تراوحت بين ( •^\% - . . (\%) ، واعتمد الباحث موافقة (^) محكمين معياراً لصلاحية الفقرة وصدقها في قياس ما وضعت لأجله بنسبة اتفاق الخبراء ( •^\%) فأكثز ، إذ أشار أيبل(Ebel, 1972) إلى أن نسبة اتفاق ( •^\%) يعد دليلاً على قبول الفقرة ، وبهذا يكون الحكم الصادر منهم مؤشراً على صدق الفقرة ونتيجة ذلك بقى عدد الفقرات (• ع) فقرة ملحق (r) ، وتحقق هذا النوع من الصدق في المقياس •

\section{r بوئشرات صدق البناء}

"بيين هذا النوع من الصدق مدى العلاقة بين الأساس النظري للمقياس وبين فقرات المقياس وإلى أب مدى يقيس المقياس الفرضيات النظرية التي بُني عليها، ويمكن التحقق من دلالات صدق البناء للمقياس بإتباع أسلوب فاعلية الفقرات، أي مدى إرتباط درجة كل فقرة من فقرات المقياس بالدرجة الكلية للمقياس، أو بقدرة المقياس على التمييز بين الفئات أو المجموعات المتباينة في أدائها على مظهر من مظاهر السلوك" ( أبو

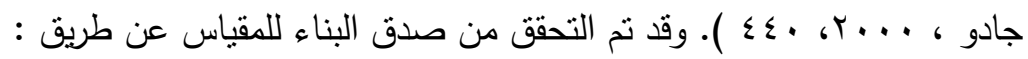

\section{أولاً: القوة التمبيزية للققرات :}

تؤثر القوة التمييزية للفقرة قدرتها على الكثف عن الفروق الفردية في الخصيصة التي يقيسها المقياس التي تقوم على اساس القياس النفسي، اذ ينبغي ان تميز الفقرة بين المستويات العليا والدنيا من الافراد في السمة او الخصيصة التي تقيسها الفقرة، لذا فأن القوة التميزية تعد اهم خصبصة من الخصائص السيكومترية لفقرات المقاييس النفسية معيارية المرجع (399 : Ebel, 1972$)$ ينبغي استبعادها او تعديلها وتجريبها من جديد والابقاء على الفقرات المميزة فقط في المقياس بصورته النهائية (Ghisselli, et.al, 1981: 421 ). ولحساب القوة التمبيزية للفقرات رتبت درجات عينة تحليل الفقرات احصائياً من أعلى درجة كلية الى أقل درجة كلية، ثم حددت المجموعتان المتطرفتان في الدرجة الكلية بنسبة

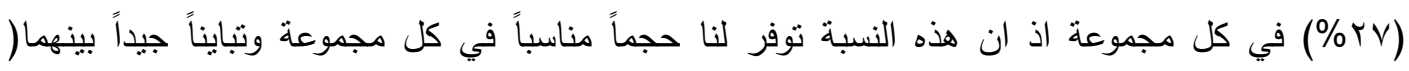


العــــــدد السادس والعشرون

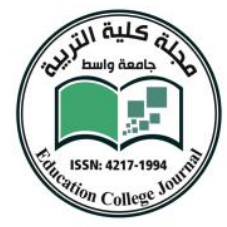

مجلــــة كليــــة التربيــــة

268 : Stanly \& Hopkins, 1972 ). وقد بلغ عدد افراد كل مجموعة من المجموعتين(YV)، وبعد

استعمال الاختبار التائي (t-test) لعينتين مستقلتين بوساطة برنامج الحاسوب الالي (spss) في حساب دلالة الفرق في كل فقرة بين المجموعتين المنطرفتين في الدرجة الكلية على اساس ان القيمة النائية الدحسوبة تمثل القوة التمييزية للفقرة ( 154-153 : Edwards, 1977 ). وعُدّت القيمة النائية المحسوبة مؤشراً لتمبيز كل فقرة من خلال مقارنتها بالقيمة الجدولية التي تساوي(91،1،) عند مستوى دلالة(0.، •.) وبدرجة حرية (7 (9) وقد نبين أن جميع الفقرات مميزة بدلالة إحصائية، والجدول (1 ) يبين ذلك.

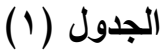

القوة التمييزية لفقرات مقياس النجاح المهني بأسلوب المجموعتين المتطرفتين

\begin{tabular}{|c|c|c|c|c|c|}
\hline \multirow{2}{*}{ القيمة التائية المحسوية } & \multicolumn{2}{|c|}{ المجموعة الدنيا } & \multicolumn{2}{|c|}{ المجموعة العليا } & \multirow{2}{*}{ الفقرات } \\
\hline & الانحراف المعياري & المتوبط الحسابي & الانحراف المعياري & المتوسط الحسابي & \\
\hline$\Lambda . r \leqslant 1$ & $.9 \leq 7 r 7$ & r.9V97 & . .VTrVT & $\Sigma . \Sigma Y \wedge T$ & 1 \\
\hline $0.7 \cdot r$ & 1. .VTN1 & זד & . Атт. & r.91人E & $r$ \\
\hline $7.7 \ldots$ & 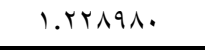 & 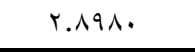 & $.7101 Y$ & $\varepsilon . r Y \leq 0$ & r \\
\hline $9 . \ldots \leq$ & $1.17 \leqslant r T$ & Y.V001 & $. T \leq \wedge \vee \wedge$ & $\varepsilon . \leq 79 \varepsilon$ & $\varepsilon$ \\
\hline$\varepsilon .1 \wedge 7$ & $1.1111 \mathrm{~V}$ & T.ITTE & $1 .+1 \cdot 10$ & $\varepsilon .+r . \varepsilon$ & $\varepsilon$ \\
\hline N.r7o & $1.109 \leqslant 1$ & r.VYOO & $.05 \ldots 7$ & $\varepsilon . r \wedge O V$ & 0 \\
\hline ק.ro & $1.1 \leqslant Y \wedge T$ & אזדוניז & $\cdot v \cdot v 11$ & $\{.0 V \mid \leq$ & 7 \\
\hline $0 . \Sigma T r$ & אד. מזיו & צ.תז & $.7 \wedge \vee 09$ & $\varepsilon \ldots \pi) r$ & V \\
\hline $0 . v 0 r$ & $1 . \cdot \varepsilon \cdot \wedge r$ & Y.รY人T & 1.. TrTV & $r, v 001$ & $\wedge$ \\
\hline $7 . \wedge \wedge 9$ & $1.1 .70 \mathrm{~V}$ & r.TVTO & .9711. & E.ITYE & 9 \\
\hline V.ANr & . & r.IYTE & .VYVYT & E.rדV & 1. \\
\hline N.OVY & $1 . .7 \cdot 77$ & $r . V I \leq r$ & . Атाт. & $\varepsilon . r \wedge \vee \wedge$ & 11 \\
\hline ג..人r & $.9 \leq 411$ & 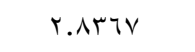 & . & 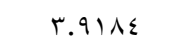 & ir \\
\hline A.rVY & . .v०9r. & r.91^ะ & 10 . & $\varepsilon .1 \cdot r$. & ir \\
\hline$\varepsilon . \varepsilon \varepsilon V$ & $1.19 . r \varepsilon$ & r..... & . Avova & r.9r^ᄉ & $1 \leq$ \\
\hline 7.747 & $1 . \cdot r \cdot T r$ & $r . v 1 \leq r$ & .v०9r. & 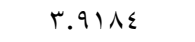 & 10 \\
\hline
\end{tabular}


العــــــدد السادس والعشرون

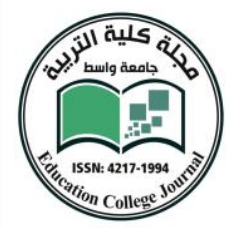

مجلــــة كليــــة التربيــــة

\begin{tabular}{|c|c|c|c|c|c|}
\hline $0 . \ldots \leq$ & $1.51 r q$ & $r . r \leq \leqslant q$ & .7707. & E.ITYE & 17 \\
\hline 0.90 & .977rV & 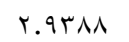 &..$\vee 9.0 V$ & $\varepsilon \ldots \ldots$ & IV \\
\hline 0.91 & $.9 \leq \leqslant \leq 7$ & r..TIr & .VTIKS & $\varepsilon \ldots \wedge 17$ & 11 \\
\hline A.YOS & I...r & r.or. T & $.9 . \leq \leqslant 0$ & E.ITYE & 19 \\
\hline V.Y.O & .10178 & r.9r^ᄉ & $. V \leqslant Y \wedge \wedge$ & s.l.Y. & $r$. \\
\hline V.rvi & $1.1 K \cdot{ }_{1}$ & $r .01 \cdot r$ & 1.10 & $\varepsilon . r \cdot \Sigma l$ & YI \\
\hline$\Lambda .7 \wedge \Lambda$ & $1 . .9 \leq 91$ & r.ryor & $1 .+7 v \leq 0$ & זrד & YY \\
\hline V.rTE & $.97 Y V \varepsilon$ & 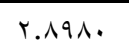 & $\therefore \wedge \vee \wedge \vee$ & $\varepsilon . r \leq \leqslant q$ & rr \\
\hline $1 . \wedge 90$ & $.971 \wedge 7$ & r.79rq & . .TITHV & $\varepsilon .1 \leqslant r q$ & $r \varepsilon$ \\
\hline 7.947 & . .99^r. & $r . \Sigma \cdot \wedge r$ & 1.10180 & r.911ะ & ro \\
\hline $7 . . T \leq$ & $1 . . r \mid \wedge V$ & r. $\varepsilon \leqslant q$. & $1 . r \leqslant V \leqslant 0$ & עדז.איז & $r T$ \\
\hline$\wedge .0 \leqslant V$ & 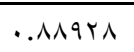 & r.v०909 & $. \wedge 1 . v_{0}$ & E.rTor & TV \\
\hline $0 . r \leq r$ & $1.001 \leq$ & r.v001 & .90 .4$. & r.^וד & $r \wedge$ \\
\hline V.rq7 & $1.1 \cdot 1 \leq 9$ & $r . . r . \varepsilon$ & $\because V \cdot \varepsilon V$ & $\varepsilon . \Sigma \cdot \wedge r$ & rq \\
\hline 0.ANr & $1.1 V V T 1$ & $r . r Y \leq 0$ &.$\pi \cdot \wedge \varepsilon$ & $\varepsilon . r \leq 79$ & $r$. \\
\hline $1.00 \leqslant$ & $1 . r$ rNo0 & r.TIYr & .79 rvo & $\varepsilon . r \leq 79$ & M \\
\hline 7.101 & $1 . . v 1 \cdot r$ & $r . r \leq \leq q$ & $\because V \cdot \varepsilon V$. & $\varepsilon . \Sigma \cdot \wedge r$ & Tr \\
\hline$\varepsilon .7 \leq \wedge$ & . АО人тr & T.ד & $.79 \wedge . r$ & E.rTVT & r \\
\hline 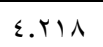 & 1.177 .7 & T.ITYE & $.719 \leq 0$ & r.9r人从 & $r \varepsilon$ \\
\hline$\varepsilon .101$ & $1.50 \times 10$ & $r .909 r$ &.$V \cdot r r_{\Lambda}$ & 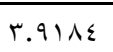 & ro \\
\hline r.АVT & . . & $r .1 \leq r q$ & $.9 \vee \wedge 90$ & r.AOVI & Tr \\
\hline T.К人 & $1.1 \leqslant 1 \% V$ & T.VY00 &.$\wedge r 7 \wedge 0$ & E..TाY & $r v$ \\
\hline & ..ААЯイ^ & r.V909 & .119090 & r.vvoo & rᄉ \\
\hline 1..r70 & .9 .9v71 & T.ร79 &.$\wedge 011 \mathrm{~V}$ & E.rYT & rq \\
\hline
\end{tabular}


"يعد أسلوب علاقة درجة الفقرة بالدرجة الكلية للمقياس من المؤشرات المستعطلة في حساب الاتساق الداخلي

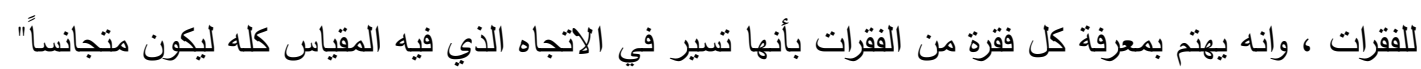

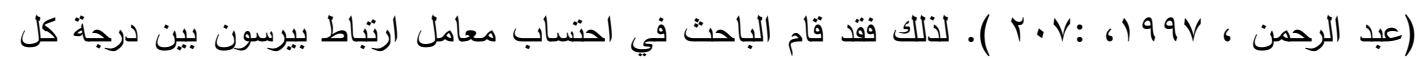

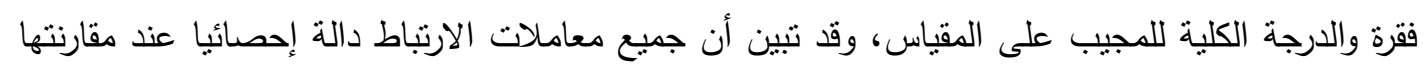

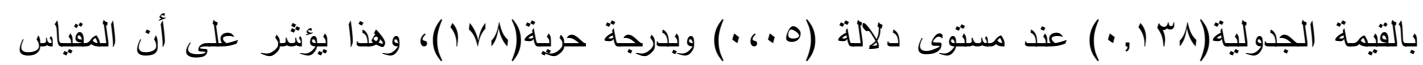
صادق لقياس الظاهرة والجدول(r) يوضح ذلك.

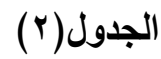

معاملات الارتباط بين درجة كل فقرة والارجة الكلية لمقياس النجاح المهني

\begin{tabular}{|c|c|c|c|c|c|c|c|}
\hline معامل ارتباط الفقرة & رقفم & معامل ارتباط الفقرة & رقم & معامل ارتباط & رقفم & معامل ارتباط & رقم \\
\hline$. \diamond \wedge \leq$ & r &..$\leqslant r V$ & rI & . $\leqslant \leqslant 4$ & 11 & $.0 \mathrm{Vr}$ & 1 \\
\hline צט r. & Tr & r & r & $.0 \leq$. & ir & $.0 \leq$. & $r$ \\
\hline$. . \leq 4 \leq$ & זי & $.7 \leq r$ & r &. .719 & 14 & $.0 \vee \wedge$ & $r$ \\
\hline.$v 19$ & $r \varepsilon$ & .. $\varepsilon q$ & $r \varepsilon$ & & $1 \varepsilon$ & . .70 & $\varepsilon$ \\
\hline . . & ro & .79 & ro &.$\Delta \wedge \varepsilon$ & 10 & . $\varepsilon$. q & 0 \\
\hline .711 & די &. $.0 V r$ & $r T$ & $\cdots 0 . r$ & 17 & צ & 7 \\
\hline .7 .9 & rv & $.7 \leq 1$ & rV & צוr. & IV & & v \\
\hline ת r. & r & דצr. & rA & .717 & 11 & $.7 v \leq$ & $\wedge$ \\
\hline$\cdots \leqslant q \wedge$ & $r q$ & .017 & $r q$ & . & 19 &.$O V Y$ & 9 \\
\hline .ror & $\varepsilon$. & $. r \leqslant V$ & r. & .0 .5 & $r$. & $.0 \leq \leqslant$ & 1. \\
\hline
\end{tabular}




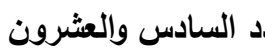

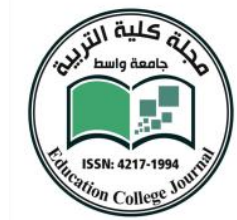

مجلــــة كليــــة التربيــــة

ثالثاً: علاقة درجة الفقرة بدرجة المجال الأي تنتمي اليه :

لتحقيق ذلك أستعمل الباحث معامل ارتباط بيرسون لاستخراج العلاقة الارتباطية بين درجة كل فقرة من

فقرات المقياس والدرجة الكلية للمجال الذي تتنمي إليه، وقد كانت جميع معاملات ارتباط الفقرات دالة

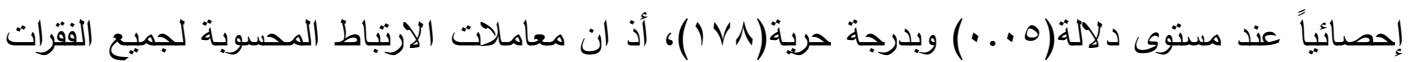

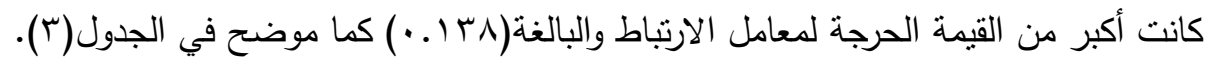

$$
\text { لجدول (r) }
$$

قيم معامل ارتباط بيرسون بين الفقرات والمجال الأي ينتمي إليه

\begin{tabular}{|c|c|c|c|c|}
\hline قيم معامل ارتباط الفقرات بالدرجة الكلية للمجال & أرقام الفقرات & عدد الفقرات & 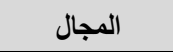 & رقم المجال \\
\hline .. & 1 & \multirow{10}{*}{1.} & \multirow{10}{*}{ مجال الاداء } & \multirow{10}{*}{1} \\
\hline .011 & $r$ & & & \\
\hline. .04 & $r$ & & & \\
\hline .71 & $\varepsilon$ & & & \\
\hline$\cdot . \wedge \wedge$ & $\bullet$ & & & \\
\hline .074 & 7 & & & \\
\hline$\rightarrow \leqslant V \leqslant$ & 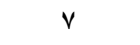 & & & \\
\hline . orr & $\wedge$ & & & \\
\hline$\cdot r \cdot r$ & 9 & & & \\
\hline . & 1. & & & \\
\hline $.00 r$ & 11 & \multirow{10}{*}{1.} & \multirow{10}{*}{ المجال المعرفي } & \multirow{10}{*}{ r } \\
\hline$\rightarrow \leqslant 1 \leqslant$ & ir & & & \\
\hline$\rightarrow 0 \leq 1$ & ir & & & \\
\hline .rrA & $1 \varepsilon$ & & & \\
\hline. .711 & 10 & & & \\
\hline . orr & 14 & & & \\
\hline..$O V Y$ & iv & & & \\
\hline .rr. & 11 & & & \\
\hline..$\leqslant \leqslant V$ & 19 & & & \\
\hline . or. & $r$. & & & \\
\hline
\end{tabular}




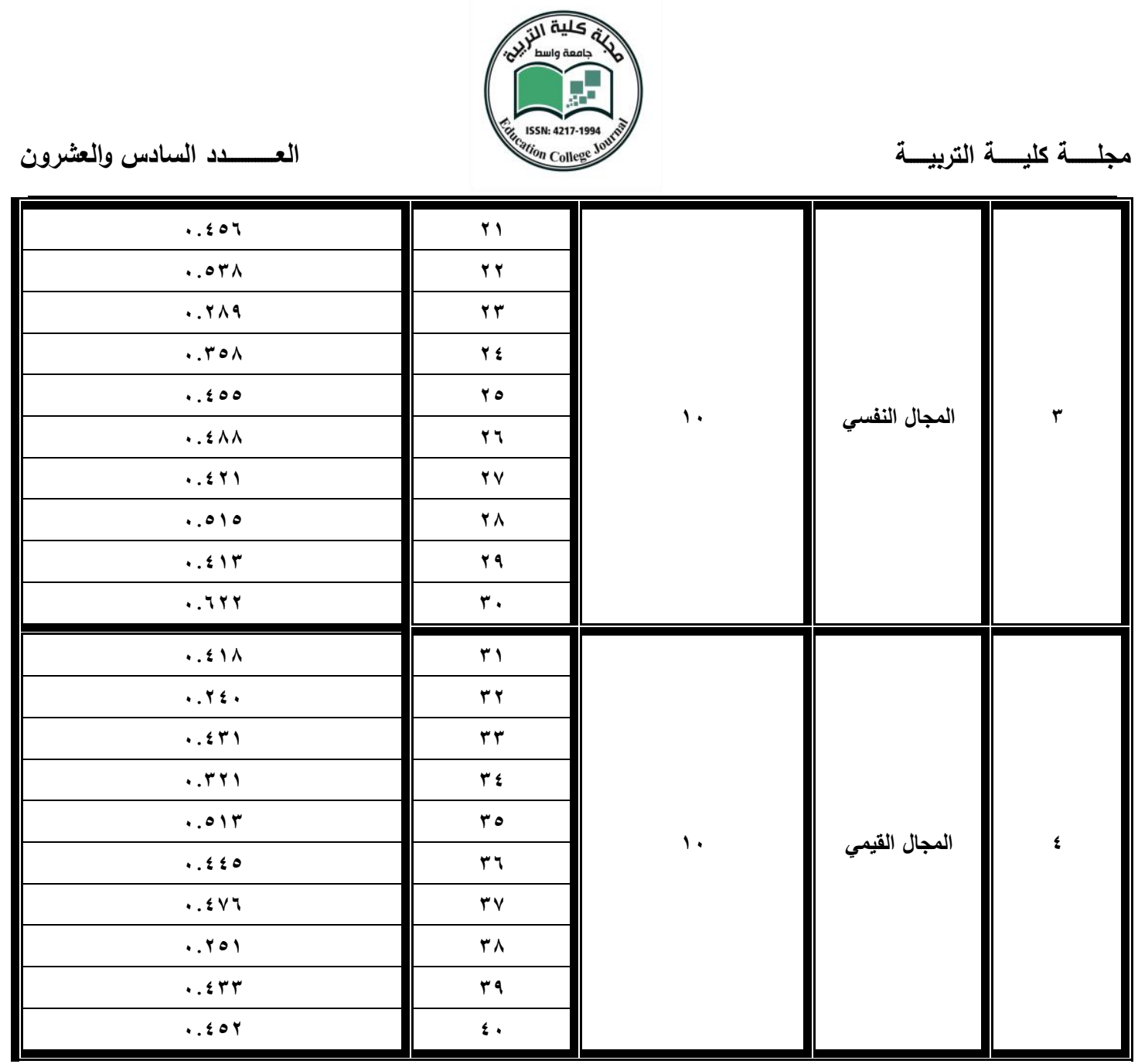

Scales Reliability ثنانياً : ثبات المقياس

" ويُقصد بالثبات في القياس النفسي " دقة الاختبار في القياس أو الملاحظة وعدم تتاقضه مع نفسه واتساقه واطراده فيما يزودنا به من معلومات عن سلوك المستجيب " ، ويعد الاختبار ثابتاً إذا كان يؤدي النتائج نفسها في حالة تكراره خاصة إذا كانت الظروف المحيطة بالاختبار والمستجيب متماثلة في كلا

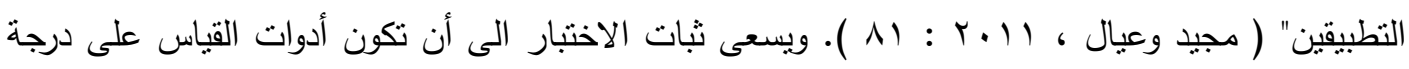
عالية من الدقة والإتقان والاتساق في ما تزودنا به من بيانات عن السلوك المفحوص، وإن متى ما كانت أداة المقياس خالية من الأخطاء العشوائية وكانت قادرة على قياس المقدار الحقيقي للسمة أو الخاصية المراد 


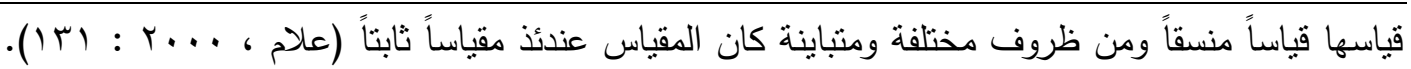
وللكثف عن مؤشرات ثنات المقياس الحالي أعنمد الباحث الطريقة الآتية :

\section{أ-طريقة إعادة الاختبار T- Retest:}

"وهي طريقة نستعمل للحصول على معامل ثبات عن طريق تطبيق المقياس مرتين على العينة نفسها

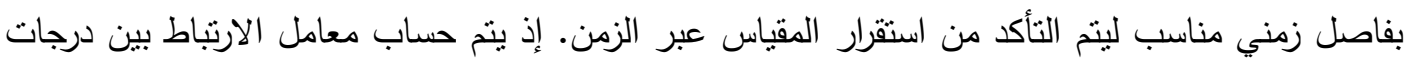

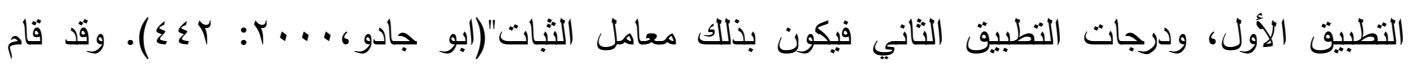

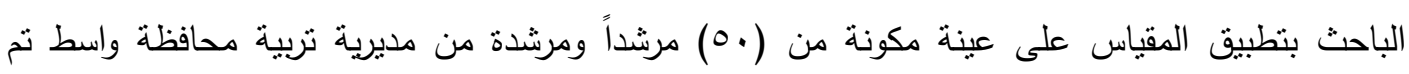

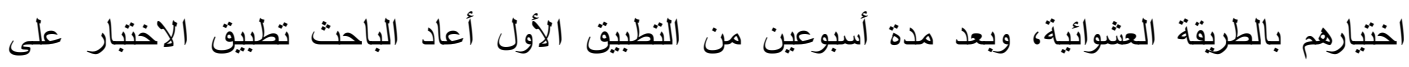

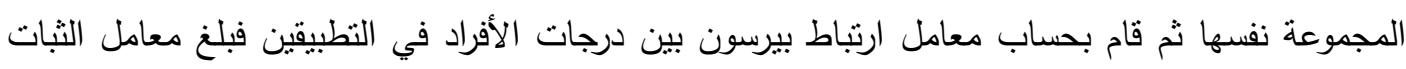

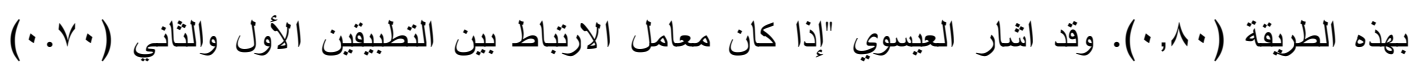

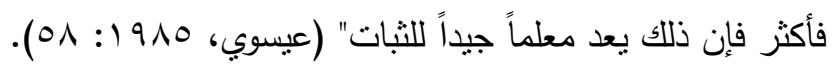

\section{ب- طريقة ألفا كرونباخ}

تعتمد هذه الطريقة على اتساق أداء الفرد من فقرة إلى أخرى (تورندايك وهيجن، 9199 : V9)، ولأجل

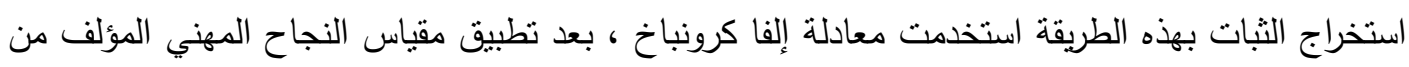

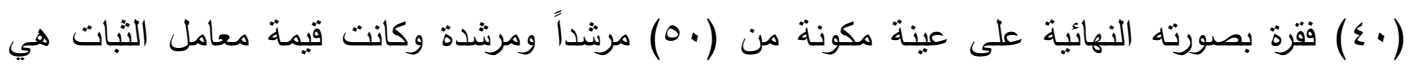

\section{وصف المقياس بصيغته النهائية:}

صيغت فقرات مقياس النجاح المهني باتجاهين( إيجابي، سلبي ) وبخمس بدائل للإجابة هي (دائماً

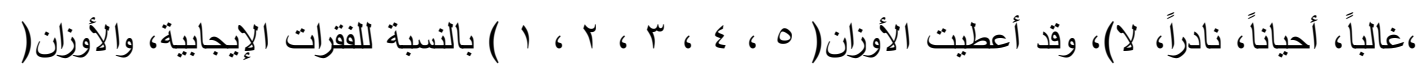

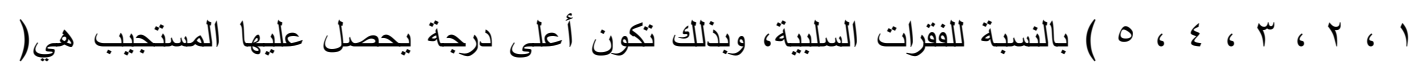

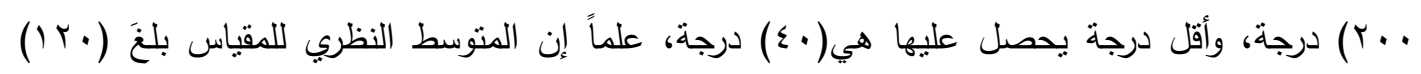
درجة. 


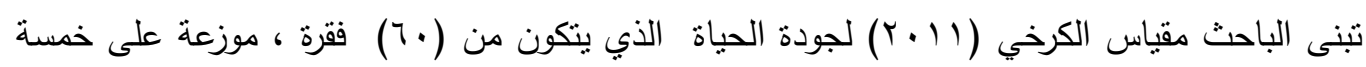

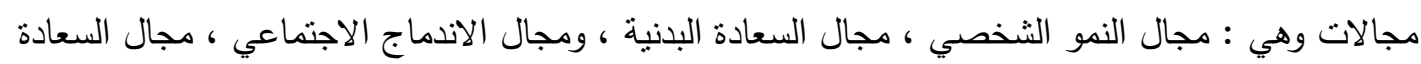

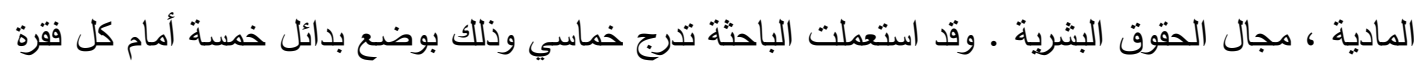

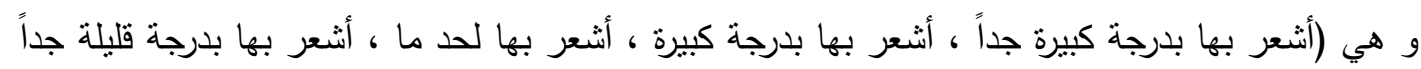

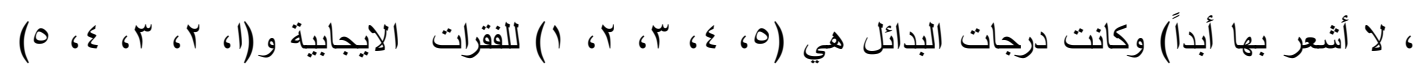

للفقرات السلبية.

الخصائص القياسية للمقياس:

اولاًَ- صدق المقياس : n

"تعد جوانب الصدق أهم خصائص الاختبارات والدقاييس التزبوية والنفسية، فالصدق من الخصائص

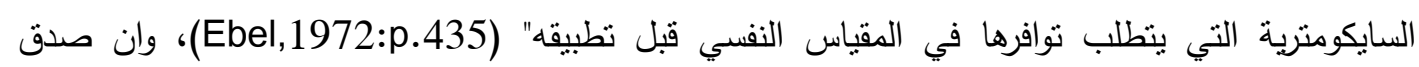

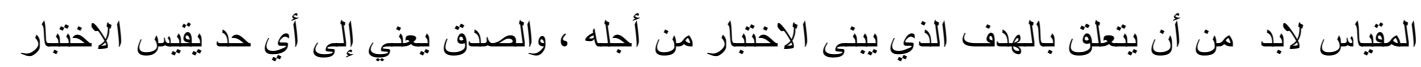

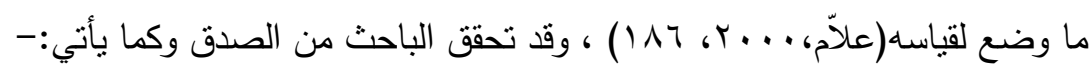

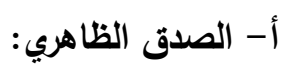

يقصد به أن المقياس يبدو انه يقيس ما أعد لقياسه ظاهرياً (Ley, 1978:p.128) · إذ أثنار أييل(Eble 1978) "إلى أن أفضل وسيلة لاستخراج الصدق الظاهري هي قيام عدد من الخبراء والمختصين

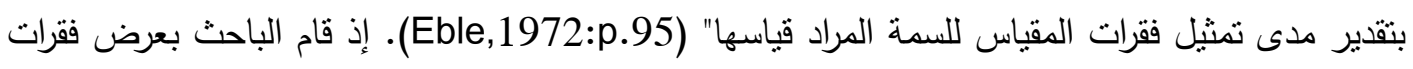
مقياس جودة الحياة وتعليماته وبدائله قبل تطبيقه على مجموعة من الخبراء والمختصين في العلوم التربوية

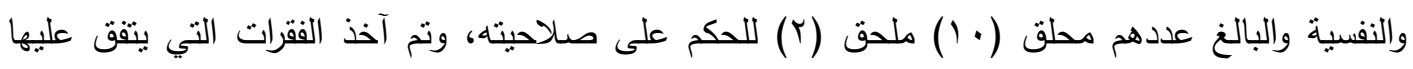


العــــــدد السادس والعشرون

مجلــــة كليــــة التربيــــة

معظمهم(•^\% فأكثر) ليصبح الحكم موضوعياً ، وبعد جمع آراء المحكمين تنين أن جميع الفقرات مقبولة وعليه بقي عدد الفقرات (·؟) فقرة ملحق (0)، وتحقق هذا النوع من الصدق في المقياس.

ثانياً - ثبات المقياس : n l n

ويؤكد جلفورد ضرورة حساب ثبات الدقياس أو الاختبار لتحديد الدرجة الحقيقة أو التباين الحقيقي ، لأن

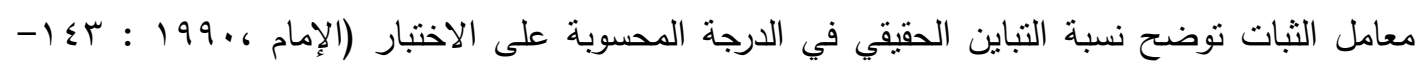
ـ ـ () ، ولغرض إيجاد ثبات مقياس جودة الحياة فقد أعتمد الباحث على طريقتين هما :

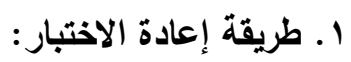

"تعد هذه الطريقة أفضل الطرائق في الحصول على الثبات، حيث تقوم هذه الطريقة على إجراء القياس

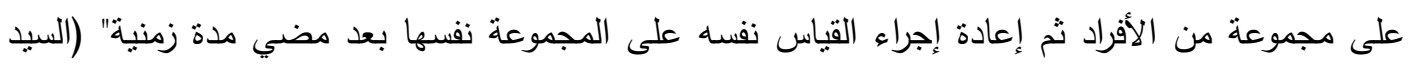

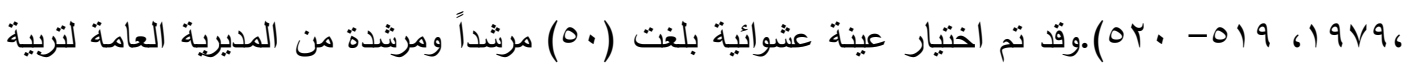

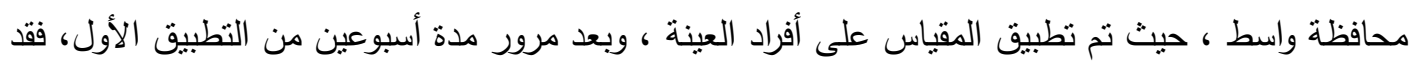

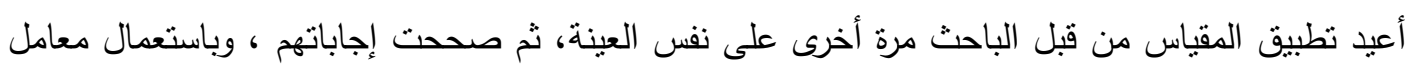

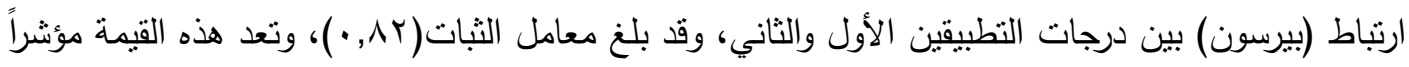

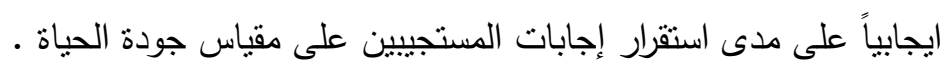

\section{r. معادلة ألفا كرونباخ(الاتساق الاخلي) :}

"تعرف هذه الطريقة بمعامل ألفا (Alpha) )،إذ اثتق كرونباخ صورة عامة لمعادلة الثبات على أساس

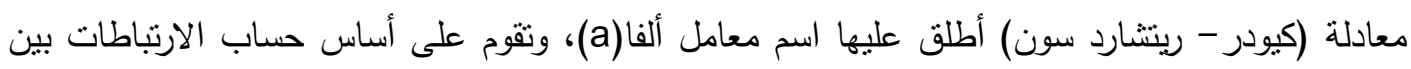

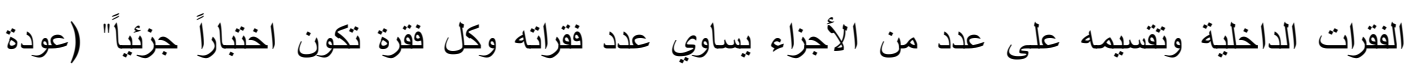

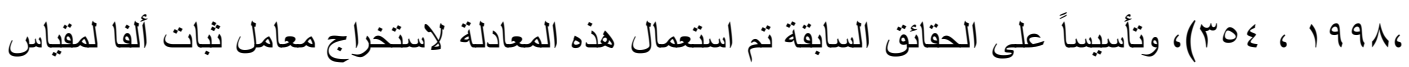

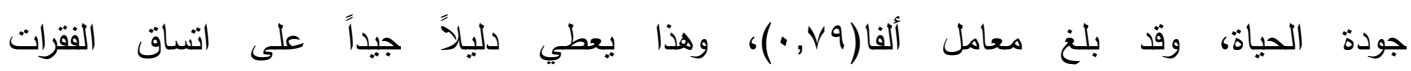
وتجانسها (Anostasi,1979:p.126). 
لمعالجة بيانات هذا البحث، استخدمت الوسائل الاحصائية الاتية، بمساعدة الحقيبة الإحصائية للعلوم الاجتماعية (SPSS) بواسطة الحاسوب.

$$
\text { 1.الاختبار التائي لعينتين مستقلتين ( T- test) : }
$$

وذللك لحساب القوة التميزية للفقرات بين المجموعتين المتطرفتين في الدرجة الكلية للمقياس ، وكذلك في

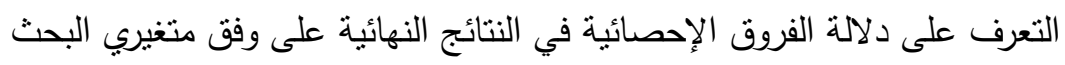

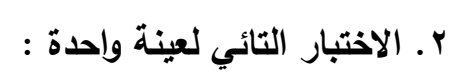

وقد استخدم لقياس النجاح المهني وجودة الحياة لدى أفراد العينة التطبيقية

$$
\text { r. الاختبار التائي لدلالة معاملات الارتباط : }
$$

استعمل لمعرفة دلالة معاملات الارتباط بين متغيري البحث الحالي النجاح المهني وجودة الحياة .

\section{ع .معامل ارتباط بيرسون:}

واستخدم لإيجاد العلاقة بين درجة كل فقرة بالدرجة الكلية لمقاييس البحث ،واستخراج الثبات بطريقة إعادة الاختبار ،وإيجاد العلاقة بين متغيري البحث

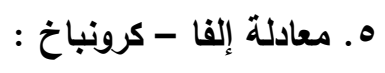

$$
\text { لحساب الثبات لمقياس النجاح المني وجودة الحياة }
$$




\section{النصل الرابع}

\section{عرض نتائج البحث وهناقشتها:}

يتضمن هذا الفصل عرضاً للتتائج التي تم التوصل إليها وتفسيرها ومناقثتها في ضوء بيانات البحث

$$
\text { الحالي. }
$$

$$
\text { الهذف الأول : التعرف على درجة النجاح المهني لدى المرشدين التربويين }
$$

أظهرت نتائج التطبيق النهائي لمقياس النجاح المني لاى المرشدين التربويين بعد تطبيق الاختبار

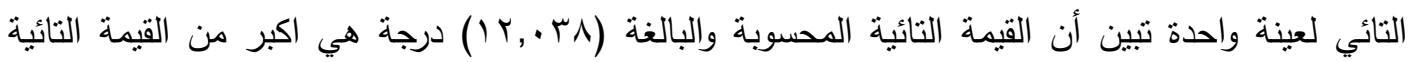

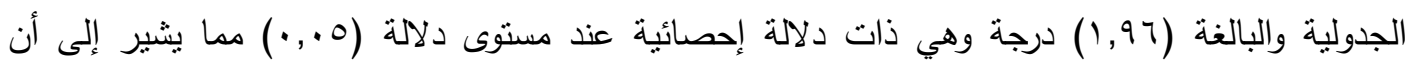

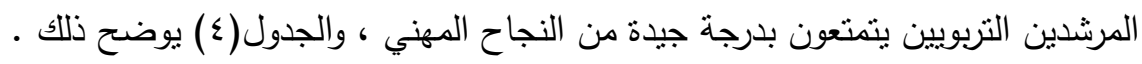

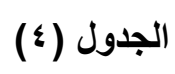

\begin{tabular}{|c|c|c|c|c|c|c|c|}
\hline الدلالة الد & القيمة التائية الجدولية & القيمة التائية & الفرضي الوسط & الاتحراف & الوسط الحسابي & العدد & المتغير \\
\hline مستوى ه . . مالة عند & 1.97 & Ir...rA & Ir. & $11.1 \leqslant 0$ & $\mid r V . \leqslant q \wedge$ & 11. & المهني \\
\hline
\end{tabular}

الاختبار التائي لعينة واحدة للفرق بين الوسط الحسابي والوسط الفرضي لمقياس النجاح المهني للمرشدين التربويين

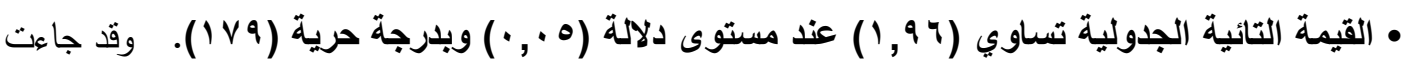

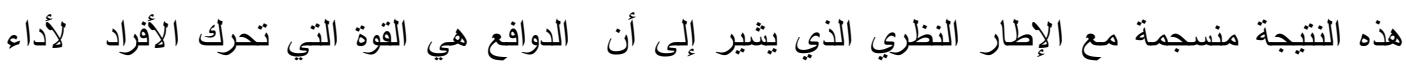

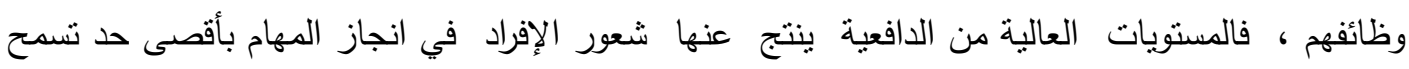

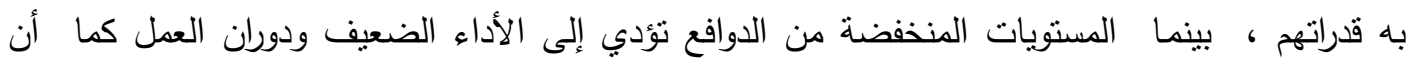

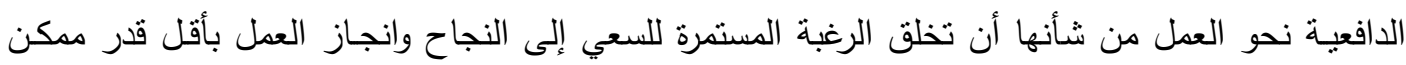

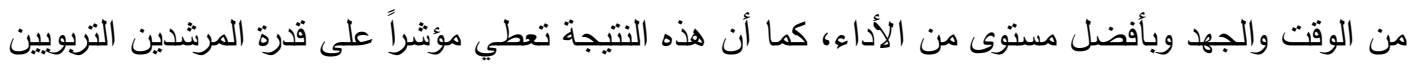

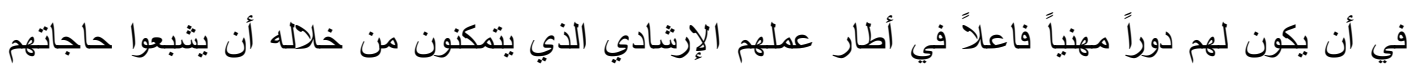


العــــــد السادس والعثرون

مجلــــة كليــــة التربيــــة

النفسية والاجتماعية وأن يحققوا مستوى مقبولاً من تحقيق الذات وتكاملها ، وتتفق هذه النتيجة مع دراسة

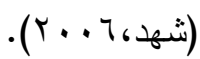

الهدف الثاني : التعرف على جودة الحياة لاى المرشدين التريويين

أظهرت نتائج التطبيق النهائي لمقياس جودة الحياة لدى المرشدين التربوبين بعد تطبيق الاختبار التائي

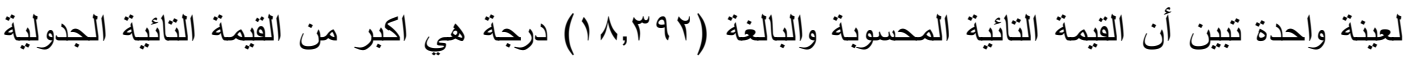

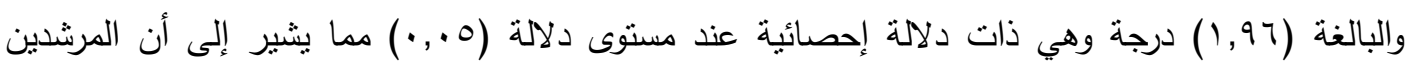

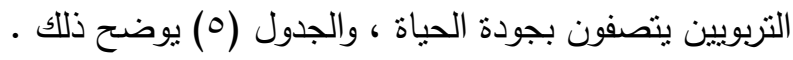

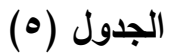

الاختبار التائي لعينة واحدة للفرق بين الوسط الحسابي والوسط الفرضي لمقياس جودة الحياة للمرشدين التريويين

\begin{tabular}{|c|c|c|c|c|c|c|c|}
\hline الدلالة & القيمة التائية & القيمة التائية & الوسط الفرضي & الانحراف & الوسط الوسب & العدد & المتغير \\
\hline دالة عند مستوى ه.,. & 1.97 & IN.rar & $1 \wedge$ & r..rio & $1 \wedge \wedge .01$. & 11. & جودة الحياة \\
\hline
\end{tabular}

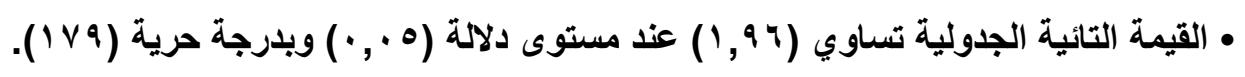

وفيما ينعلق بنتيجة الهدف الثاني التي تشير إلى أن المرشدين التربويين لديهر جودة حياة جيدة فقد اتفقت

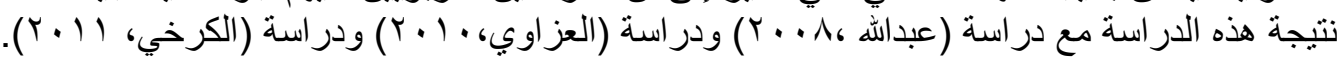

الهدف الثالث : التعرف على العلاقـة بين النجاح المهني وجودة الحياة لدى المرشدين التربويين :

للاتحقق من الهدف الثالث الذي يتضمن تعرف العلاقة بين النجاح المهني وجودة الحياة لاى المرشدين التربويين ، قام الباحث بتطييق معامل ارتباط بيرسون بين الدرجة الكلية لأفراد العينة على مقياس النجاح

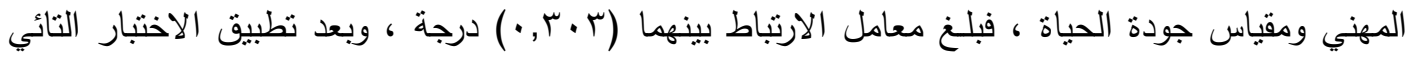

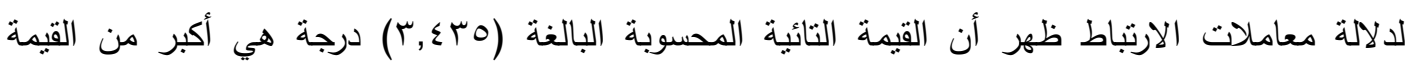

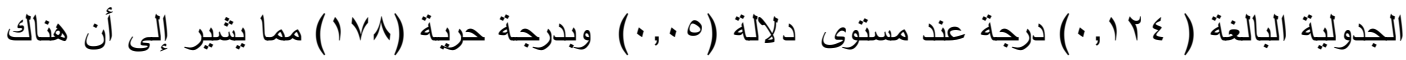


علاقة موجبة ودالة إحصائيا بين درجات متغيري البحث النجاح المهني جودة الحياة والجدول (†) يوضح

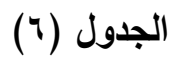
ذللك .

طبيعة العلاقة بين النجاح المهني وجودة الحياة لاى المرشدين التربويين

\begin{tabular}{|c|c|c|c|c|}
\hline 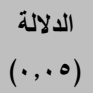 & القيمة التائية & القيمة التائية المحسوية & العدد & قيمة معامل الارتباط بين النجاح المهني وجودة الحياة \\
\hline دالة & . & ه. & 11. & $\cdot r \cdot r$ \\
\hline
\end{tabular}

إذ تدل هذه النتيجة على إن المرشدين التربويين يمتلكون نجاح مهني جيد وهم ايضاً يتصفون بجودة حياة

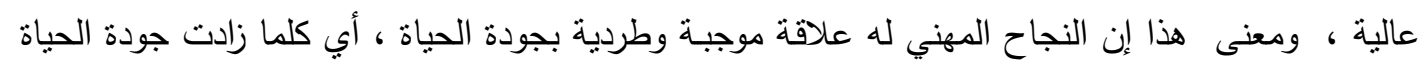

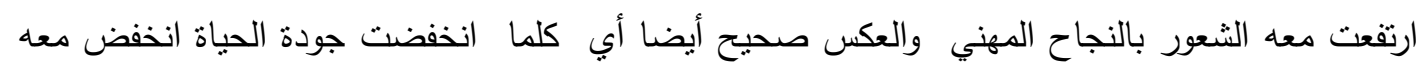

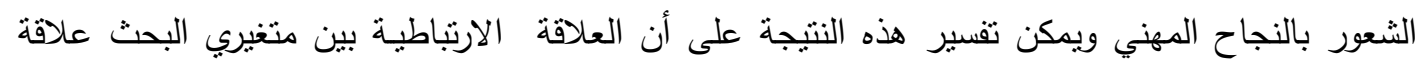
دالة وموجبة أي أن المتغيرين مرتبطان مع بعضهما البعض ،و يمكن من خلال معرفة احدهما التتبؤ

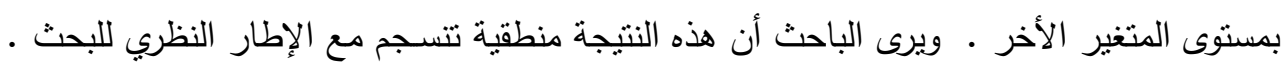

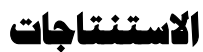

من خلال معطيات البحث الحالي استتتج الباحث الآتي :

1- أن المرشدين النزبويين في محافظة واسط يتصفون بمستوى جيد من النجاح المهني.

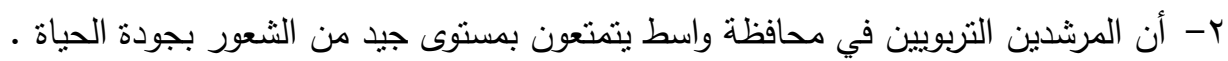
r- هناك علاقة ارتباطية طردية دالة وموجبة بين النجاح المهني وجودة الحياة . 


\section{في ضوء النتائج التي تّم التوصل اليها البحث الحالي يوصي الباحث بما يأتي:}

ا- الاهتمام بالبحوث التي تجري على المرثدين التربوبين وخاصة تلك التي تنتاول الحالات الصحية والنفسية والاجتماعية والمهنية ، والأخذ الاهنمام بتوصيات التي تطرح تلك البحوث لغرض نطوير شخصية المرشد التربوي باعتباره المسؤول عن تطوير وبناء الأجيال الذي بطهح إليها الثعب العراقي. r- العمل على إقامة دورات وورش إرشادية التي تقوم على توعية المرشدين التربوبين وخاصة الذين ليس لايهم الخدمة والخبرة الكافية. r- توجيه وسائل الإعلام الى أهمية المرشد التربوي في العملية التعليمية والتربوية . ع - الاهتمام بمشكلات المرشدين التربوبين من قبل الجهات المسؤولة عن تقدم وتطوير العملية الإرشادية. ه- تقديم التعزيز المعنوي المتمنل في كتب الثكر ، والثهادات التقديرية وتكريم المرشدين والمرشدات التربويين المتميزين في عملهم الإرشادي داخل المدارس أو في علاقاتهم التفاعلية مع الجهات الإدارية التابعين لها ، وذلك لتعزيز شعورهم بقيمة عملهم الإرشادي الذي ينعكس إيجاباً على شعورهم بنجاحهم المهني . צ- امكان استعمال مقياس النجاح المهني من قبل وزارة التربية ومديريات التربية في جميع المحافظات وكذلك شعب الارشاد التربوي لتقيم عمل المرثدين التربويين. V تعزيز الجوانب الايجابية لنجاح المهني لدى المرشدين التربوبين لكي يتمكنوا من مواجهة الصعوبات التي تواجهم في عملهم الإرشادي ^- عدم تكليف المرشد النفسي المدرسي بمحظورات العمل الارشادي في المدرسة حتى لا تعطله عن القيام بهذا الدور • 9- زيادة أعداد المرشدين النفسيين التربويين في المدارس حتى تتوفر فرص أفضل للمرشد النفسي ليقوم بدور فعال مع عدد محدود من الطلاب. 


\section{يقترح الباحثان في ضوء النتائج والتتوصيات مايأتي :}

1- إجراء دراسة تبحث في العلاقات بين جودة الحياة ، ومفاهيم نفسية وتربوية أخرى ، منل ، والصحة النفسية ، ومواجها الضغوط ، الرضا الوظيفي ، والانجاز في العمل لدى المرشدين التربوبين.

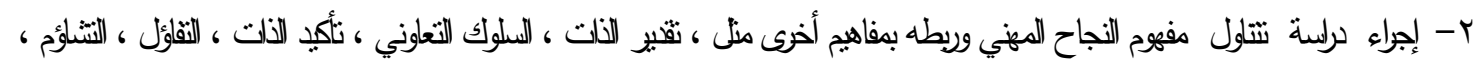

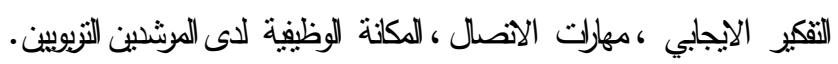

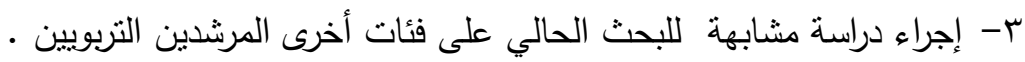

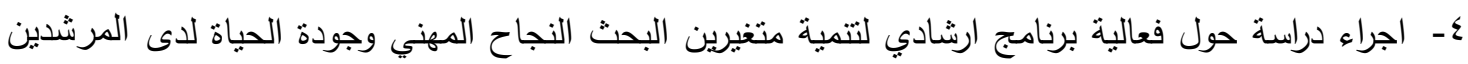
التربويين. 


\section{مصادر البحث العربية والاجنية}

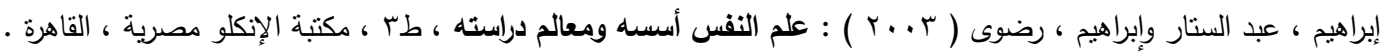

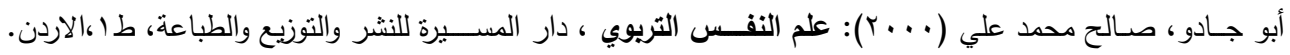

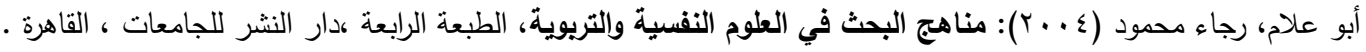

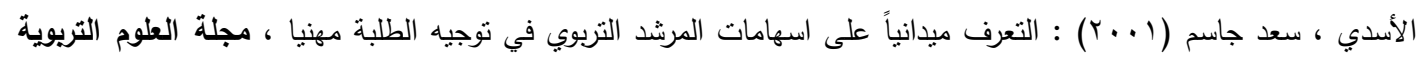

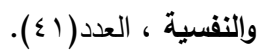

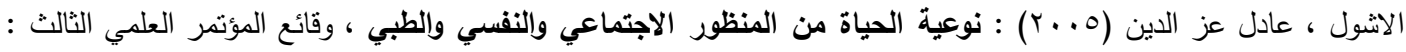

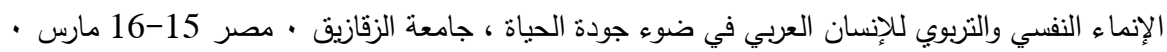

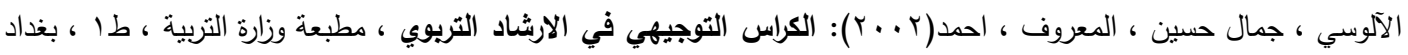

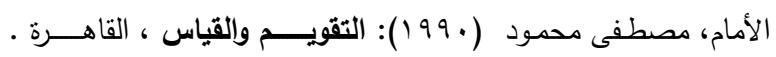

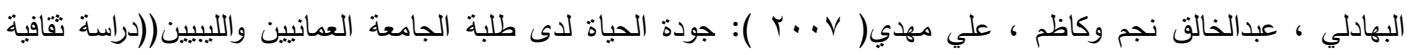

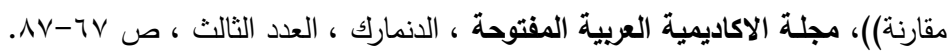

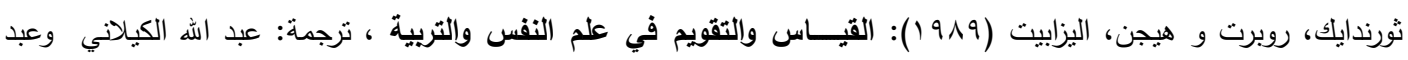
الرحمن عدس، مركز الكتاب العربي

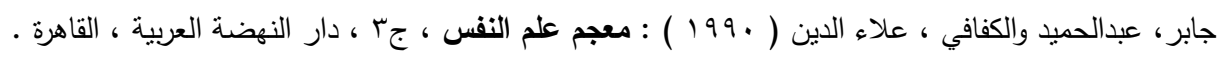

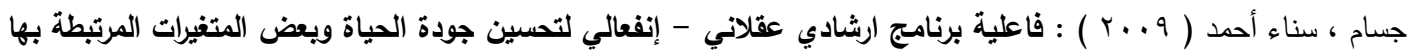

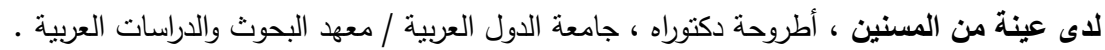

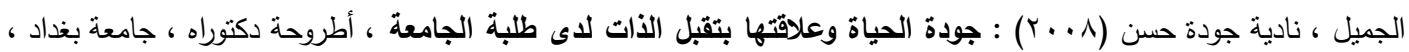

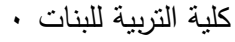

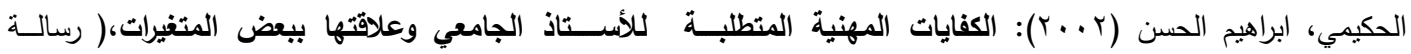

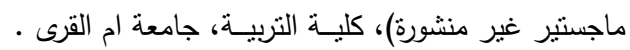
الخفاجي ، زينب حياوي بديوي ( \199 ) ) : قياس الأمن النفسي لموظفي وموظفات الدولة ، رسالة ماجستير ، جامعة بغداد/ كلية الآداب . الدراجي ، حسن السيد (• (·r) : فاعلية الذات الارشادية وعلاقتها بالرضا عن العمل الارشادي لدى المرشدين التربويين في

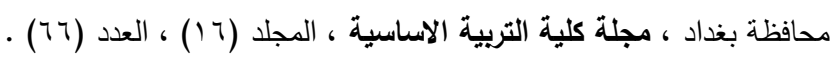

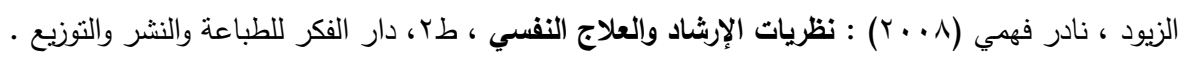

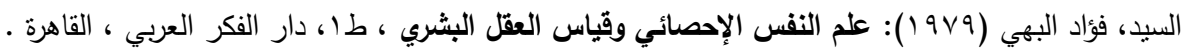

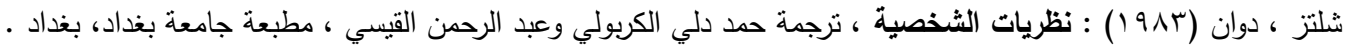


شهر ، عباس شمران (T + . r) : النجاح المهني وعلاقته بالجنس والعمر والتأهيل والرضا الوظيفي للمرشدين التريويين ، رسالة

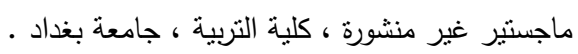

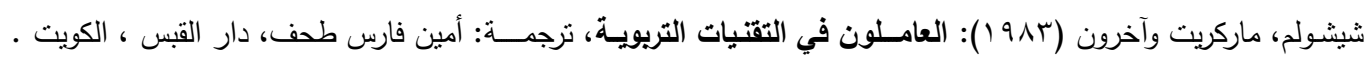
عاشور ، احمد صقر ( 9 1 1): ادارة القوى العاملة ، الدار الجامعية.

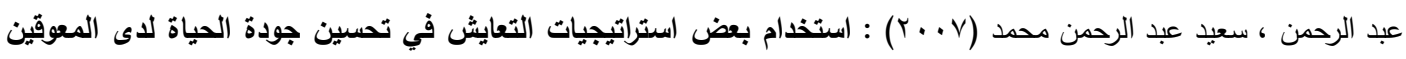

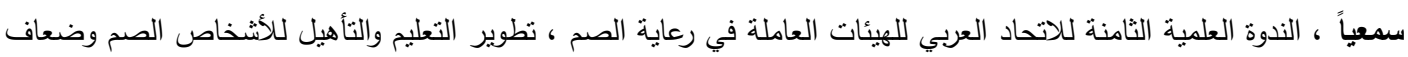
السمع.

عبد الرحمن، سعد (991 (1)): القياس النفسـي النظريــــــة والتطبيق، دار الفكر العربي ، القاهرة .

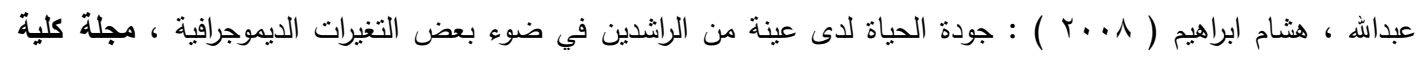

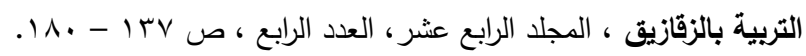

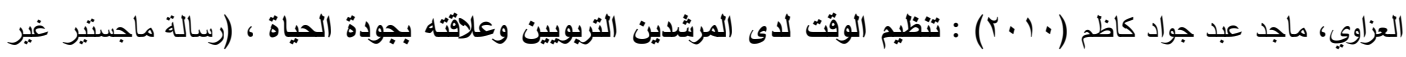
منشورة) ، كلية التربية ، الجامعة المستتصرية.

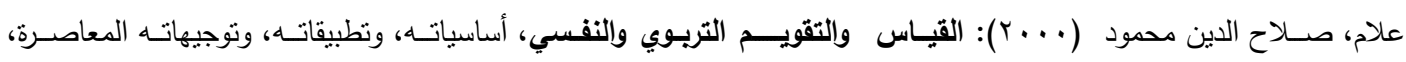

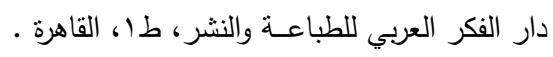

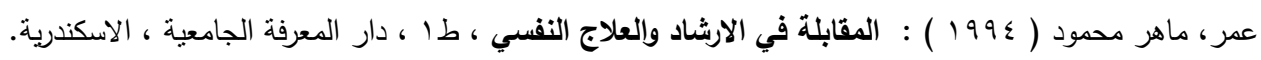

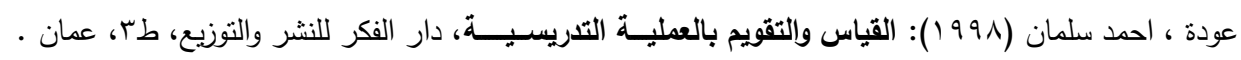

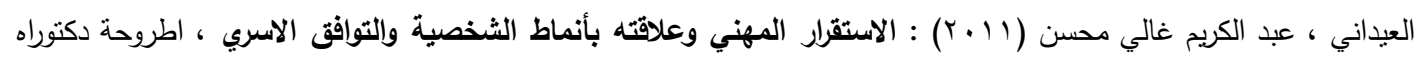

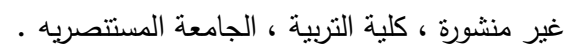

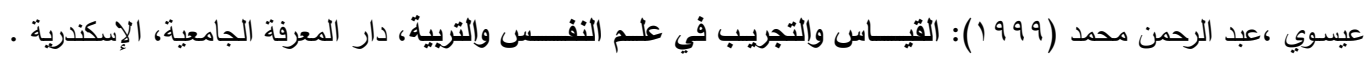

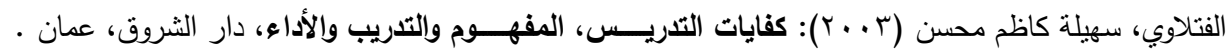

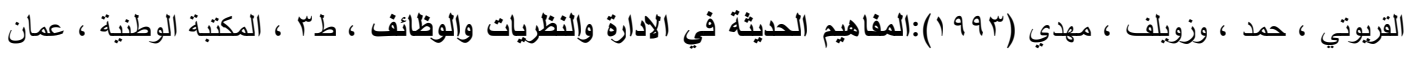

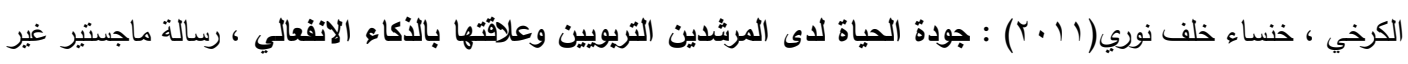

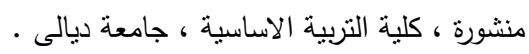

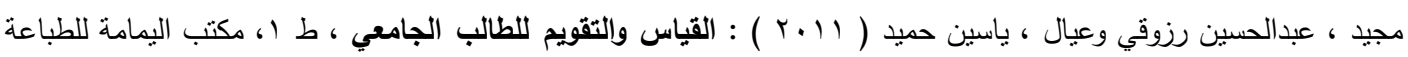
والنشر ، بغداد.

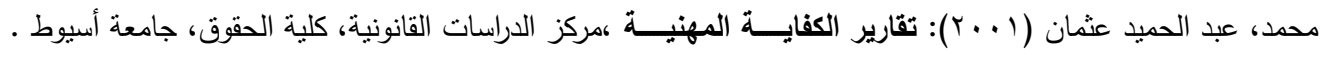
محمود ، حمدي شاكر ( 1991 ) : التوجيه والإششاد الطلابي للمرشدين والمعلمين ، ط ا 1 ، دار الاندلس للنشر والنوزيع ،

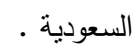

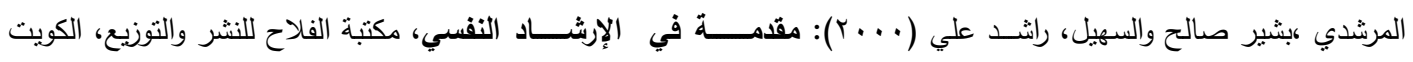




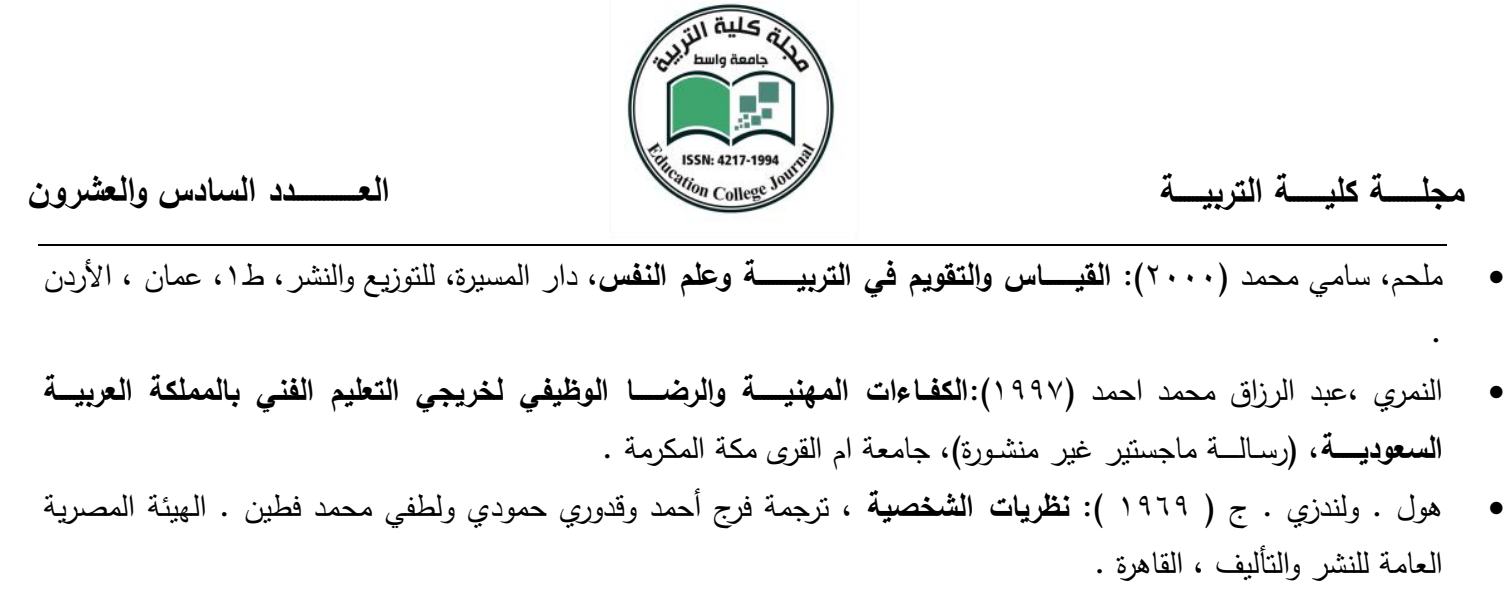

- Anastasi , Ame . (1988): Psychological testing, New York the MacMillan Company

- Beecher, M. (1990): Happiness and Marriage, Erasmus university.

- Cumins,R.,(1996):The comprehensive Quality of life Scale: Instryment Development and Psychometric Evaluation on College staffogical and student;Education\& Psychological Measurement,Vol.54(2).PP372-383.

- Eble, R. L (1972): Essentials of education measurement Ed, practice hall Englewood cliffs . New Jersey .

- Edwards, A. L . (1977): Techniques of attitude scales construction, New York corset Inc.

- Ellis (1980): The principle and practice rational Eomotive therapy, London.

- Ghiselli, E.E . Campbell, J.P. \& Zedeck, S. (1981): measurement for Behavioral Sciences. San Francisco, W. H. Freeman \& co, P.421 .

- Ley, P . (1978): Quantitative Aspects of psychological Assessment. An introduction, London. Gerald Duck worth .

- Martin, P. and Silvia, S. (1991): Influences of Socioeconomic Status, Social Network and Competence on Subjective Well-Being in Later Life: A meta-analysis. American Psychological Association, 15 (2): pp197-224.

- $\quad$ Myers , D . J . (1995) : psychology • worth publication Inc, New York .

- Stanly \& Hopkyn . (1972): Reality therapy as a better Alternative Journal of Reality, therapy

- Taylor. S J . \& Bogdan R . ( 1996 ): Quality of life and the individual's perspective . In Quality of life : Conceptualisation and measurement . Ed . R . Schalock American Association on Mental Retardation . Washingtan . D . C.

- Thomas, L.E, \& Robbins, P., I. (1979):Personality and environments, Journal of occupational Psychology.

- Viterso , J ., ( 2004 ) : Suqjective well - being versus self - actuolization : Using the flow simplex to promote a conceptual clarification of supjective quality of life, social Indicators Research, vol . 65 ( 3 ), pp $299-307$. 
ملحق (1)

استبيان استطلاعي للمرثدين التريويين

المرشد الفاضل / المرشدة الفاضلة

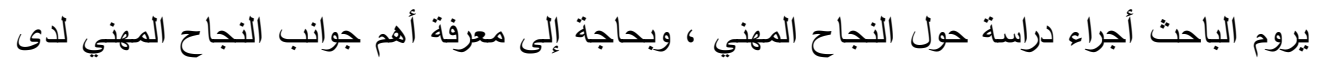

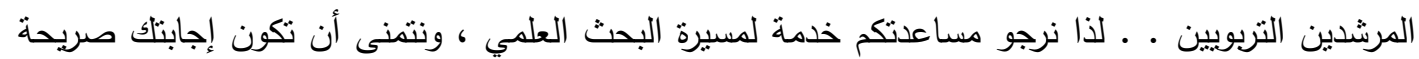

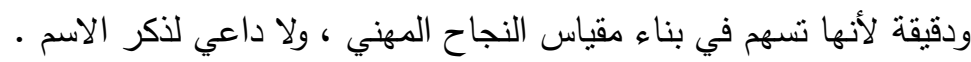

\section{مع خالص الثكر والامتنان ....}

س : ما أهم الجوانب التي تثعرك بالنجاح المهني ؟ س : ما أهم الجوانب التي تعوق النجاح المهني ؟ 
أسماء السادة المحكمين المتخصصين في العلوم التريوي والنفسية الذين حكما على صلاحية فقرات المقياسين

\begin{tabular}{|c|c|c|}
\hline 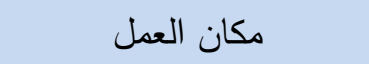 & 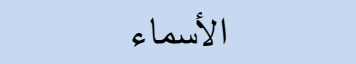 & $ت$ \\
\hline جامعة واسط / كلية التربية & ا. د. صالح نهير الزاملي & 1 \\
\hline جامعة واسط / كلية التربية & ا. د. عبود جواد راضي & $r$ \\
\hline جامعة واسط / كلية التربية & ا. د. اسيل عبد الكريم & $r$ \\
\hline جامعة واسط / كلية التربية & ا.م .د. رشيد ناصر خليفة & $\varepsilon$ \\
\hline جامعة واسط / كلية التربية & ا.م.د علي عجة الثمري & 0 \\
\hline جامعة واسط / كلية التربية & ا.م.د رضاب الخالدي & 7 \\
\hline جامعة واسط / كلية التربية & ا.م .د شيماء نصيف & V \\
\hline جامعة واسط / كلية التربية & ا.م .د عبداله مجيد العتابي & $\wedge$ \\
\hline جامعة واسط / كلية التربية & م.د سلام غياض العتابي & 9 \\
\hline جامعة واسط / كلية التربية & م.د عبد كاطع سموم & 1. \\
\hline
\end{tabular}


العــــــد السادس والعشرون

مجلــــة كليــــة التربيـــة

ملحق (r)

((استبانه اراء المحكمين في مدى صلاحية فقرات مقياس النجاح المهني))

.

الأستاذ الفاضل

تحية عطرة .....

يسعى الباحث اجراء بحثة الموسوم ( النجاح المهني وعلاقته بجودة الحياة لدى المرشدين التربوبين) ولعدم توفر اداة مناسبة لقياس النجاح المهني اعد الباحث اداة لقياس النجاح المهني بعد اجراء دراسة استطلاعية للعينة والاطلاع على الدراسات والأطر النظرية القريبة للففهوم وضع الباحث تعريف للنجاح المهني بانه : ((هي قدرة المرشد على القيام بالمهام التي تطلبها مهنة الارشاد بمستوى معين من الاتقان يضمن تحقيق اهداف الارشاد بشكل فعال )) وفي ضوء هذا التعريف حدد الباحث مجالات المقياس وهي (مجال الاداء المهني ، المجال المعرفي ، المجال النفسي ، المجال القيمي )) وفي ضوء هذه المجالات صاغ الباحث بشكل اولي فقرات كل مجال . علماً إن بدائل الإجابة عن المقياس هي (دائماً، غالباً ، احياناً ، نادراً

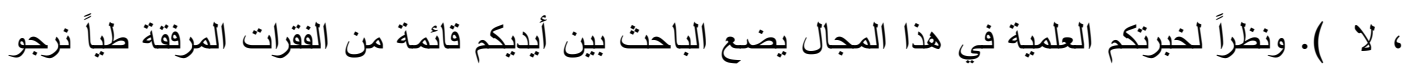
تفضلكم في تقدير مدى صلاحية هذه الفقرات أو عدم صلاحيتها ومدى مناسبتها للمجال أو عدم مناسبتها

وإجراء التعديلات المناسبة.

مع خالص الشكر والتقدير

الباحث

م.د. مالك فضيل القريشي

$\varepsilon r q$ 
العــــــدد السادس والعشرون

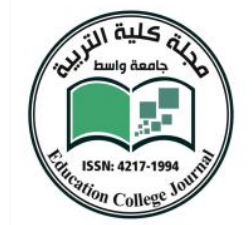

مجلــــة كليــــة التربيــــة

اولاً: مجال الاداء المهني:هو مدى قدرة المرشد على تقديم الخدمات الارشادية وتوظيفه بالعمل.

\begin{tabular}{|c|c|c|c|c|}
\hline المناسب & غير صالحة & صالحة & 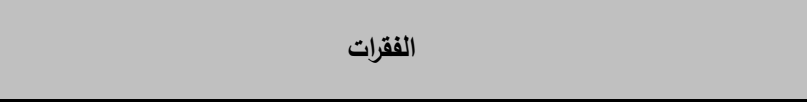 & $ت$ \\
\hline & & & اوظف فنيات المقابلة الارشادية في جلسات الارشاد الفردي . & 1 \\
\hline & & & انظم جلسات الارشاد الجمعي بكفاءة ومهنية لتحقيق الاهداف المعدة من اجلها . & r \\
\hline & & & اتواصل بفاعلية مع الطلاب في الجانب الانساني والمهني & $r$ \\
\hline & & & اساعد المسترشد لاتخاذ القرار المناسب لحل مشكلته. & $\varepsilon$ \\
\hline & & & اوظف الاختبارات والمقاييس للتشخيص حالات الطلبة في العملية الارشادية. & - \\
\hline & & & اقدم الدعم النفسي للطلبة ذوي الاحتياجات الخاصة . & 1 \\
\hline & & & امتلك القرة على تثخيص الحالات التي بحاجة للتحويل الى الجهات المختصة . & $v$ \\
\hline & & & احرص على عمل النشرات الارشادية داخل المدرسة & $\wedge$ \\
\hline & & & احرص على اعداد خطة العمل الارشادي الفصلية والثهرية & 9 \\
\hline & & & امتلك مهارة ادارة اجتماعات مجلس الاباء والمدرسين . & 1. \\
\hline
\end{tabular}

ثانياً: المجال المعرفي: هو مدى ادراك المرشد ومعرفته بمجال تخصصه العلمي من معلومات ومعارف وافكار واستراتيجيات ونظريات في مجال الارشاد .

\begin{tabular}{|c|c|c|c|c|}
\hline التعديل المناسب الت & غير صالحة & 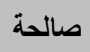 & 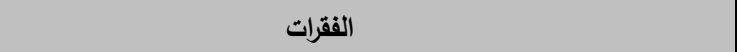 & $ت$ \\
\hline & & & احرص على متابعة التطورات الحديثة في مجال الارشاد. & 1 \\
\hline & & & | امتلك القدرة على فهم وتقسير سلوك المسترشد . & r \\
\hline & & & احرص على حضور المؤتمرات والتدوات المرتبطة بمهنتي. & $r$ \\
\hline & & & الاكاديمي · الاستراتجيات المعرفية الفعالة لمساعدة الطلبة في مجال التحصيل & $\varepsilon$ \\
\hline & & & | أرى مهنتي تتناسب مع تخصصي العلمي . & 0 \\
\hline & & & احرص على تطبيق النظريات الارشادية في العملية الارشادية & 1 \\
\hline & & & |ستطيع معرفة جوانب القوة والضعف في العمل . & $\mathrm{v}$ \\
\hline & & & |حرص على تنظيم انشطة لا صفية للطلبة . & $\wedge$ \\
\hline
\end{tabular}




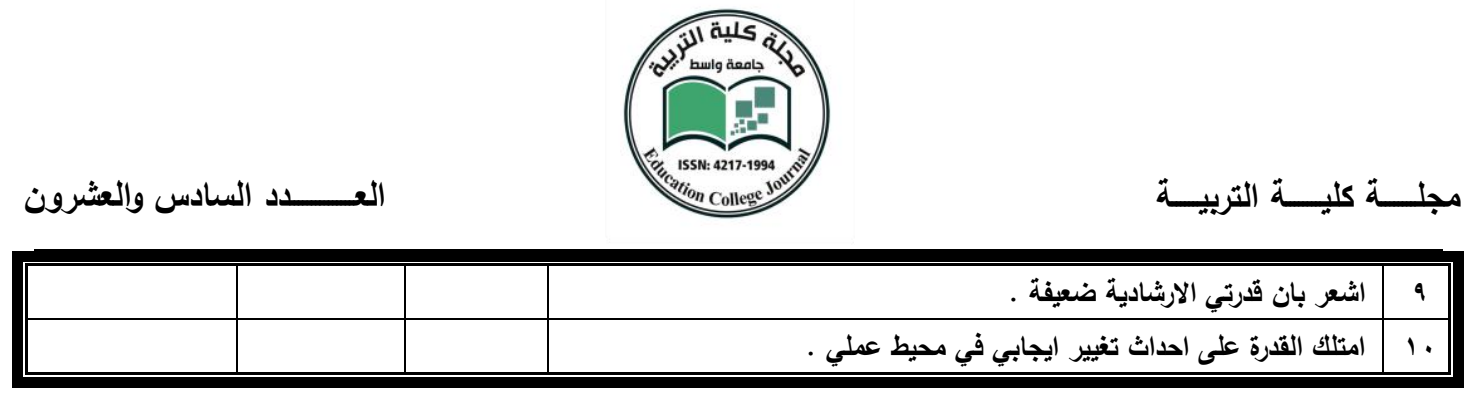

ثالثاً: المجال النفسي : هو رضا الفرد عن مهنته ومطابقة هذه المهنة مع حالته العلمية والنفسية

\begin{tabular}{|c|c|c|c|c|}
\hline التعديل المناسب المب & غير صالحة & 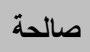 & 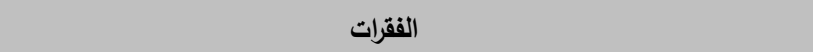 & $ت$ \\
\hline & & & اشعر بالأمن والاستقرار اثثاء ممارسة مهنتي . & 1 \\
\hline & & & اشعر ان مهنتي تتلائم مع ميولي ورغباتي . & r \\
\hline & & & يشكك الاخرون بالحلول التي اضعها للمشكلات . & $r$ \\
\hline & & & اشعر بتفضيل زملائي علي في العمل . & $\varepsilon$ \\
\hline & & & يولمني ضعف اهتمام الاخرين بعملي . & $\bullet$ \\
\hline & & & انتهز اي فرصة لأغير مهنتي . & 7 \\
\hline & & & ينتابني الملل والضيق اثناء العمل . & $v$ \\
\hline & & & اشعر بالفخر عندما اخبر الاخرين عن مهنتي . & $\wedge$ \\
\hline & & & اشعر بالسعادة عذما انجح في مساعدة الطلبة واحداث تغير ايجابي في سلوكهر . & 9 \\
\hline & & & يفتقر عملي الى غرفة نموذجية & 1. \\
\hline
\end{tabular}

لابعاً: المجال القيمي: هو التزام المرشد بمبادىء وقيم واسس واخلاقيات الارشاد النفسي والتربوي.

\begin{tabular}{|c|c|c|c|c|}
\hline 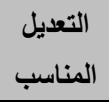 & غير صالحة & 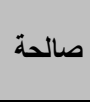 & 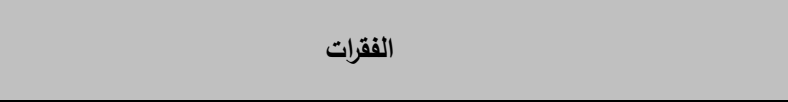 & ت \\
\hline & & & احترم مبادى وإخلاقيات العمل الارشادي والتزم بها & 1 \\
\hline & & & احترم المتطلبات القانونية والأخلاقية في قضايا الملفات الساخنة. & r \\
\hline & & & احترم مواعيد العمل والتزم بها. & r \\
\hline & & & اقدم خدمات الارشّاد للمسترشدين بغض النظر عن الجنس او المعتق & $\varepsilon$ \\
\hline & & & اشجع الطلبة على احترام القوانين والتعليمات المدرسية والالتزام بها ـ . & $\circ$ \\
\hline & & & احرص على تغيير بعض الاتجاهات السلبية عن مهنة الارشاد . & 1 \\
\hline & & & المساعدة بله. & V \\
\hline & & & احرص على تنمية الوعي الديني والاخلاقي لاى الطلبة & $\wedge$ \\
\hline & & & اثجع الطلبة على العمل الجماعي ويث روح المحبة والتسامح بين الطلبة. & 9 \\
\hline & & & استثمر علاقتي مع المسترشدين لتحقيق مكاسب شخصية . & 1. \\
\hline
\end{tabular}




\section{الملحق (؛)}

\section{مقياس النجاح المهني بصورته النهائية}

عزيزتي المرشدة: عزيزي المرشد:

بين بديك مجموعة من الفقرات أرجو الاجابة عليها بالبديل الذي ينطبق عليك وذلك بوضع علامة ( ل ) امام البديل الذي يعبر عن وجهة نظرك علما ان إجابتلك لا تستخدم الا لأغراض البحث العلمي ولن بطلع عليها احد.

$$
\begin{aligned}
& \text { ملاحظة: ارجو الاجابة على جميع الفقرات بكل صدق وصراحة ولا نترك واحدة دون اجابة }
\end{aligned}
$$

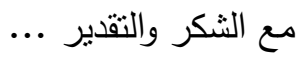

الباحث م. د : مالك فضيل عبداله 


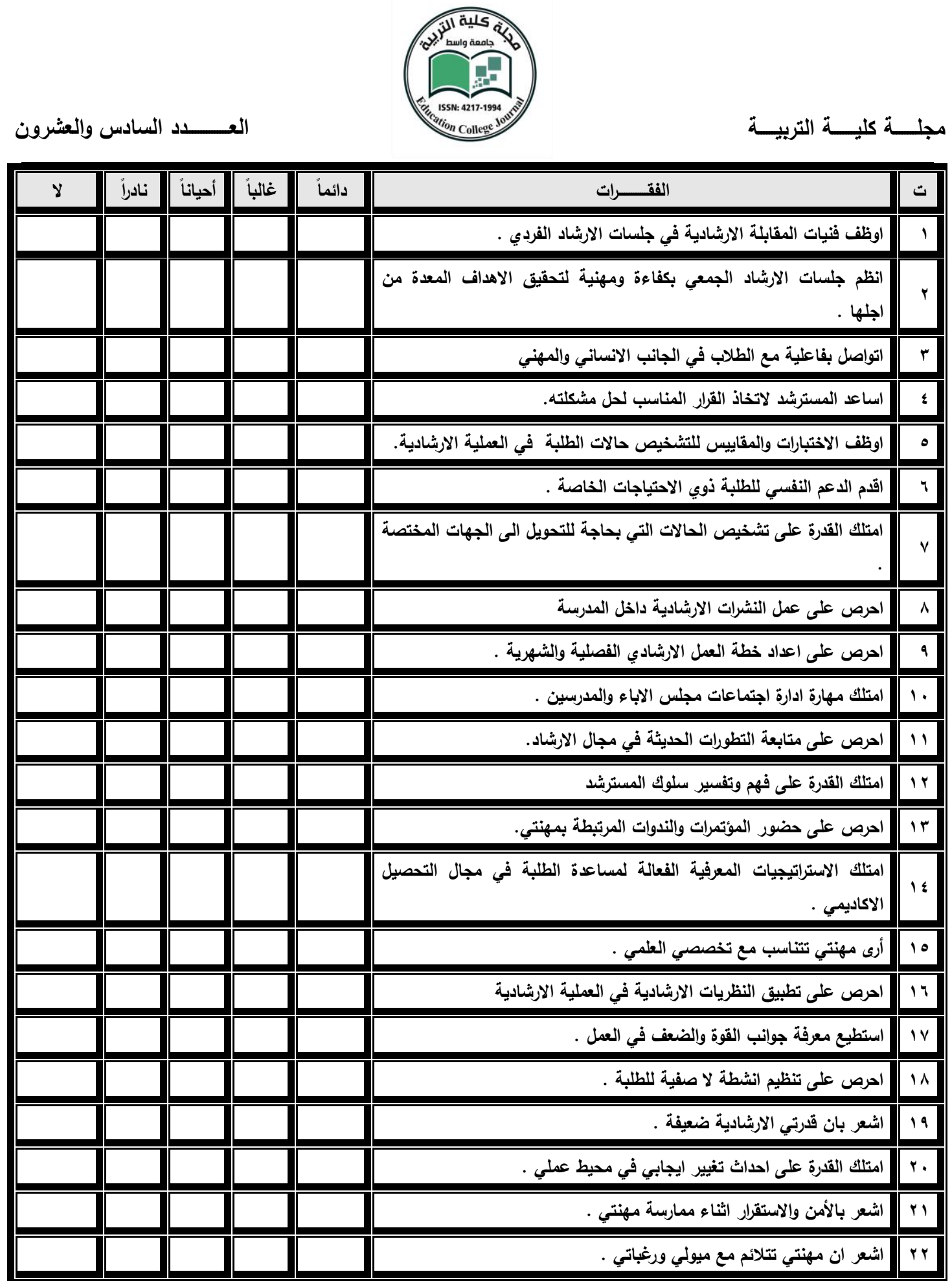




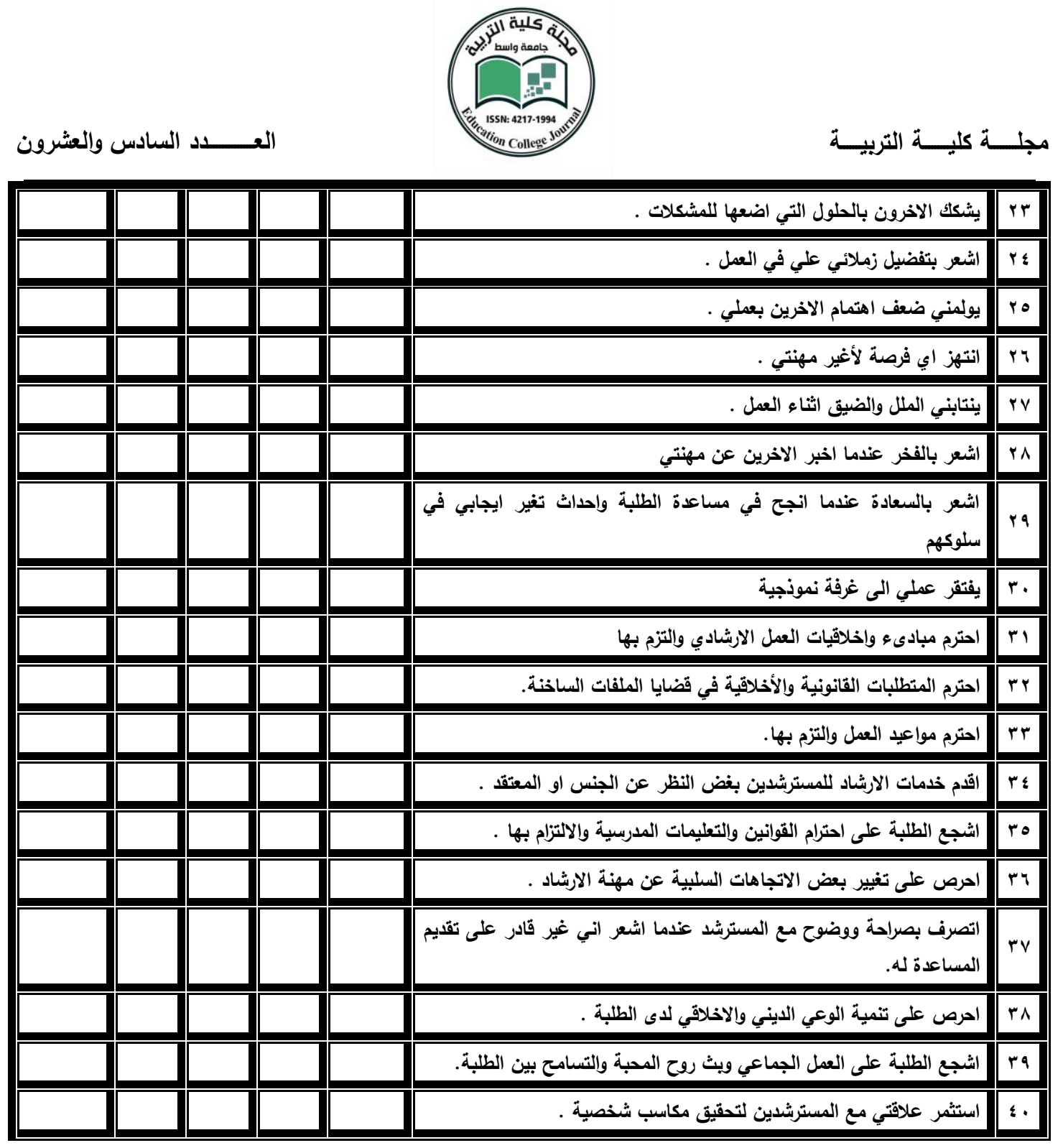


(0) (الملحق )

مقياس جودة الحياة بصورته النهائية

عزيزتي المرشدة : عزيزي المرشد

بين يديك مجموعة من الفقرات أرجو الاجابة عليها بالبديل الذي ينطبق عليك وذلك بوضع علامة ( ل )

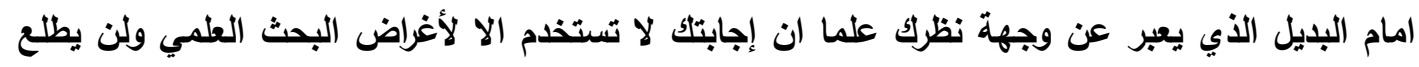
عليها احد

ملاحظة: ارجو الاجابة على جميع الفقرات بكل صدق وصراحة ولا تترك واحدة دون اجابة مع الثكر والتقدير

\section{الباحث}




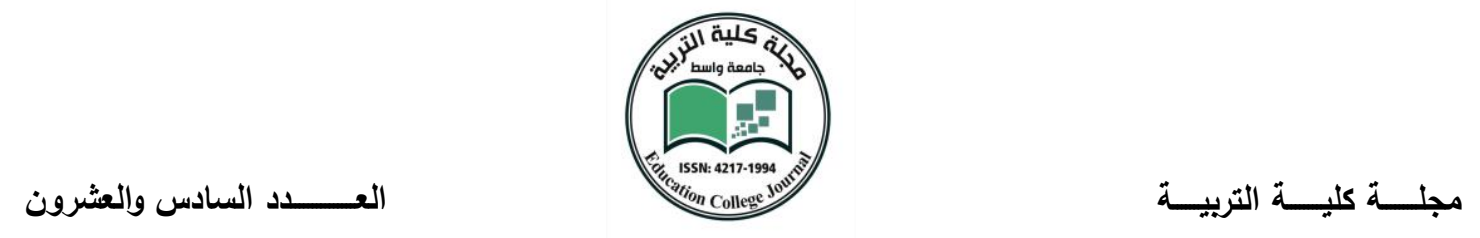

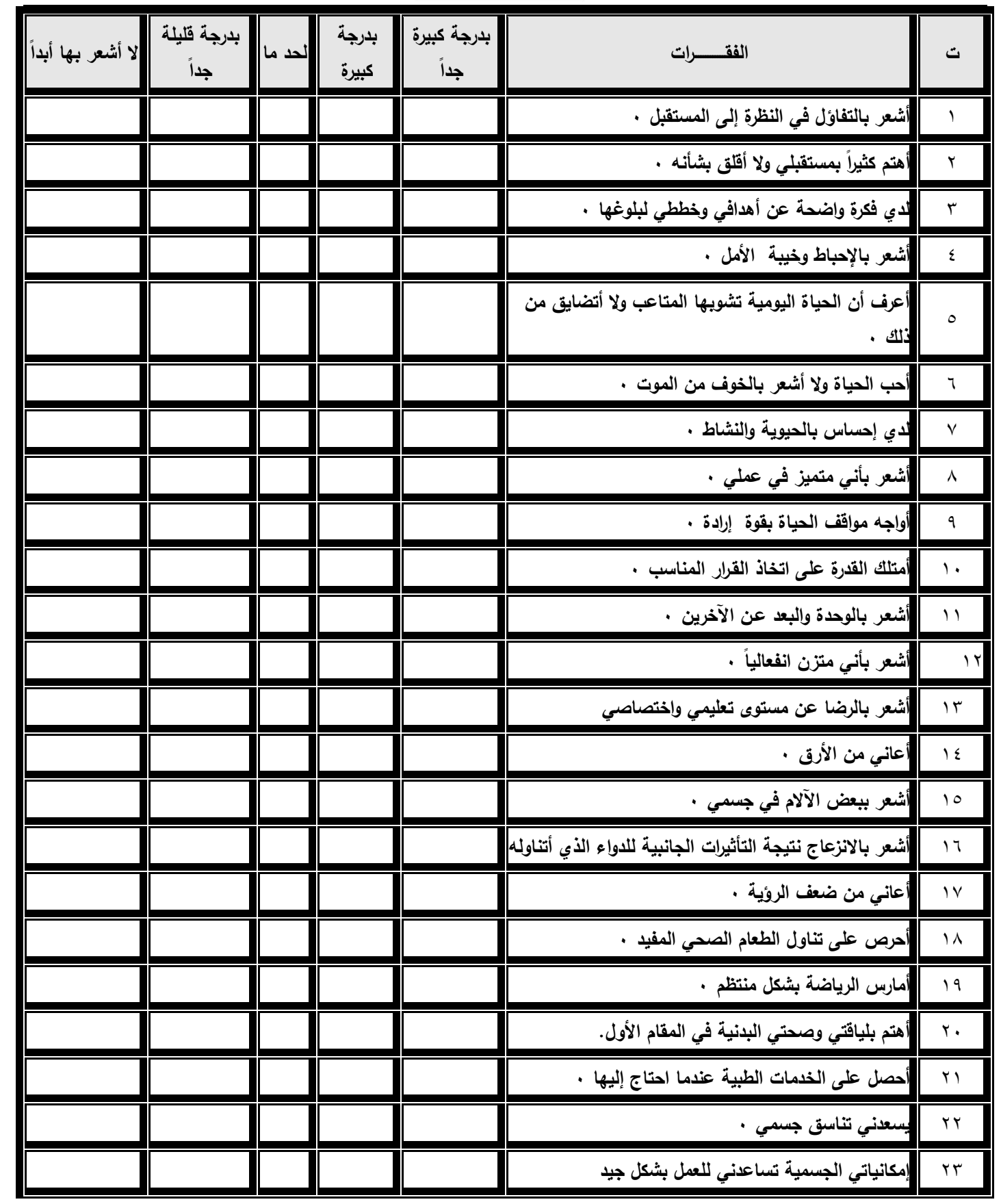




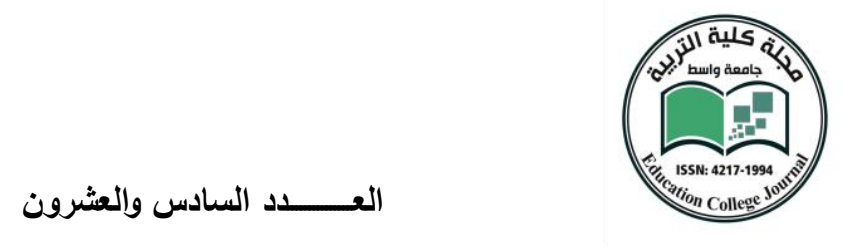

مجلـــة كليــــة التربيــــة

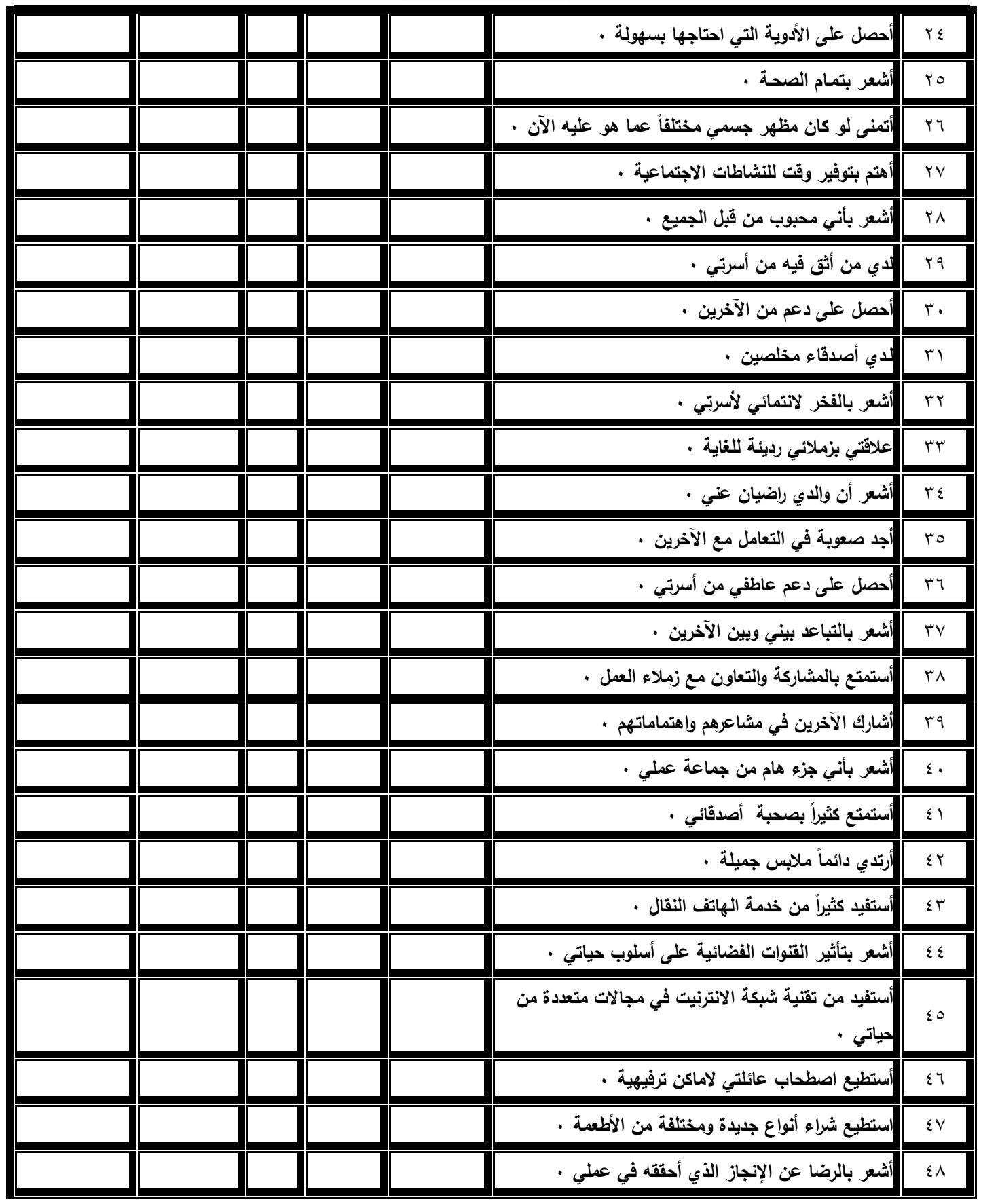




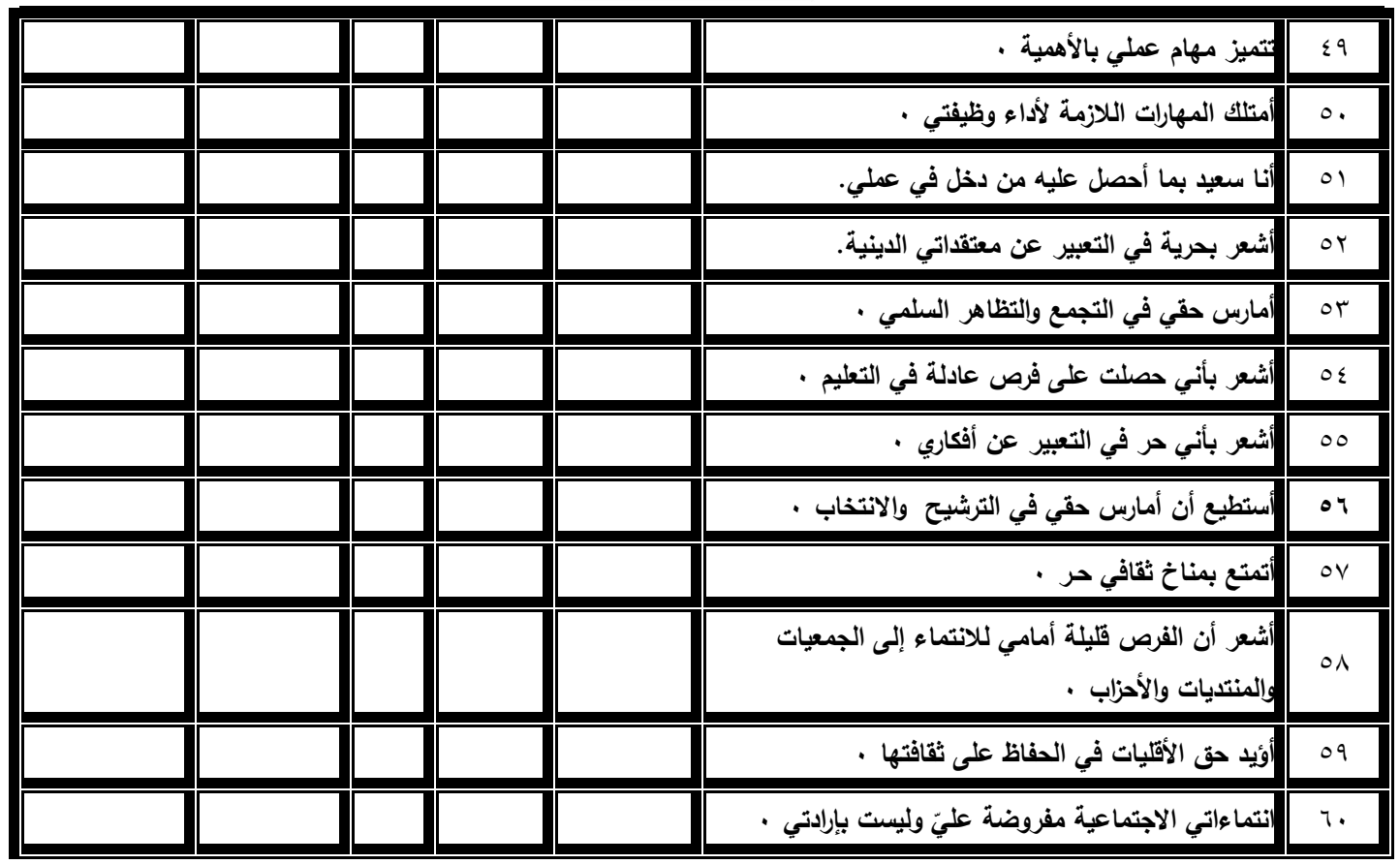

